\title{
Musicology Australia
}

Journal of the Musicological Society of Australia Volume $30 \quad 2008$

(-) 


\section{Musicology Australia}

Contents

Volume $30 \quad 2008$

All articles in this volume have been peer reviewed by at least two experts.

Published by The Musicological Society of Australia, Inc.

GPO Box 2404

Canberra ACT 2601

Australia

www.msa.org.au

(C) 2008 The Musicological Society of Australia

The Musicological Society of Australia is affiliated with the

International Musicological Society (IMS) and the

International Council for Traditional Music (TTCM)

Editor Paul Watt

Associate Editor Dorottya Fabian

Review Editor Jennic Shaw

Editorial Advisory Committee

Linda Barwick

Mark Carroll

Deborah Crisp

Mark Evans

Hugh de Ferranti

John Griffiths

Rosalind Halton

Jane Hardie

Kerry Murphy

Samantha Owens

Graeme Smith

David Symons

Peter Tregear

National Committee, 2007-8

John Griffiths (President)

Melanie Plesch (Secretary)

Peter Campbell (Treasurer)

Philip Wheatland (Membership Secretary)

Victoria Rogers (Ex officio Past President)

Margaret Kartomi (Ex officio IMS Representative)

Allan Marett (Ex officio ICTM Representative)

Brydie-Lcigh Bartleet

Rosalind Halton

Steven Knopoff

Alicia Maguire

Kathleen Nelson

Jason Stoessel

Text design and typesetting Perry Karipidis

Cover design Theo Politis

Printed in Australia by On Demand

Editorial

PAUL W

Corresponde

Michae

\section{Articles}

Wild N

Syd

KATE B

Before

of ]

DAvit

Review Art

Arnhe

In'

Prtel

Lives

Suzal

From

at

KaTH

'The

F

Alt.

Hist

$\mathrm{NiCl}$

Reviews

The

Mis

$O p$

$\mathrm{M}_{3}$

M

M 


\section{Contents}

\section{Editorial}

PAUL WATT

\section{Correspondence}

Michael Kassler

\section{Articles}

Wild Men and Mystics: Rethinking Roy Agnew's Early

$$
\text { Sydney Works }
$$

Kate Bowan

Before Corroboree: Toward a Clearer Perspective of the Early Music of John Antill

DAVID SYMONS

\section{Review Articles}

Arnhem Land on the Agenda in Reccnt Texts on Australian Indigenous Music and Dance

Peter Dunbar-Hall

Lives in Music: Recent Studies of Nineteenth-Century Organists Suzanne Cole

From the Republic of Slovenia: Slovenian Music History and Musicology

Kathleen Nelson

'The words stink and the music is just pathetic': The Making of a

Popular National Anthem in New Zealand

Allan Thomas

Historically Illuminating Performance

Nicholas Routley

\section{Reviews}

The Company We Keep: An Intimate Celebration of Opera Australia, by Annarosa Berman and Bridget Elliot

Michael. Halliwell

Opera from the Greek: Studies in the Poetics of Appropriation, by Michacl

$$
\text { Ewans }
$$

Michael Halliwell

Music Divided: Bartók's Legacy in Cold War Culture, by Danielle

Fosler-Lussier

Malcolm Gillies 
Music and Love: Music in the Lives of Italian Australians in Griffith, New South Wales, by Roland Bannister

Paul Ashron

A History of Baroque Music, by George J. Buelow Paul Watt

Kathi.fen Nelson

The Resisting

Tan Peddi

A Briefe and Short Instruction of the Art of Musicke by Elway Bevin, edited by Denis Collins

Michael Kassler

Thomas Roseingrave: Complete Keyboard Music, edited by H. Diack Johnstone and Richard Platt

Rosalind Halton

Desperate Measures: The Life and Music of Antonia Padoani Bembo, by Claire Fontijn

LIONEL SAWKins

The Works of Henry Purcell, Volume 27: Symphony Songs, edited by Bruce Wood

David Newsholme

Louis Grabu, Albion and Albanius, edited by Bryan White

David Newsholme

Thomas Tallis and his Music in Victorian England, by Suzanne Cole Katharine Pardef.

Malcolm Arnold-A Composer of Real Music: Sympbonic Writing, Style and Aesthetics, by Raphael D. Thöne

Rhoderick McNeill

Peter Sculthorpe: The Making of an Australian Composer, by

Graeme Skinner

Suzanne Robinson

Music and Theology: Essays in Honour of Robin A. Leaver, edited by Daniel Zager

Stepinanie Rocke.

Composition, Chromaticism and the Development of Process: A New Theory of Tonality, by Henry Burnett and Roy Nitzberg

Simon Perry

French Music Since Berlioz, edited by Richard Langham Smith and Caroline Potter

Clair Rowden

Berliaz and Debussy: Sources, Contexts and Legacies: Essays in Honour of François Lesure, edited by Barbara L. Kelly and Kerry Murphy

Clair Rowden 
Dance and Dancers in the Victorian and Edwardian Music Hall Ballet, by Alexandra Carter

PAUL WaTT

The Resisting Muse: Popular Music and Social Protest, edited by Ian Peddie

Michael Webb

Guidelines for Contributors

MSA Membersbip 


\title{
Wild Men and Mystics: Rethinking Roy Agnew's Early Sydney Works
}

kesman', ts at the ditional Sydney it 'Miss stone.

The Era at the ert was orks by 'Miss talent; on, not ney.

\author{
KATE BOWAN
}

In June 1921 'Ultramodern Extravagance'-a revicw of a British Music Society concert that was staged at the Sydney Conservatorium as part of Director Henri Verbrugghen's lecture-chamber concert series-appeared in the Australian Musical News (hereafter $A M N$ ). Although critical of the entire programme, the review was particularly scathing of the excesses of a young Sydney composer, Roy Agnew. Notwithstanding his cleverness as a composer, in the case of Dance of the Wild Men and Toccata Tragica, the critic fumed that Agnew's better judgment had been obscured by 'ultramodern extravagance'. The $A M N$ critic reported the opinions of his fellow Sydney critics, who, 'while usually so mild, meek, good-natured and never-say-an-unkind word about anything or anyone', were on this occasion provoked into being 'unanimous in telling some home truths about the compositions played'. He isolated for particular attention one writer's almost melodramatic charge that 'a concert like this was calculated to do real harm to the cause of British music'. Recovery from the trauma inflicted by this concert was apparently slow. Days later, one member of the large and apparently forward-thinking audience was still in shock, declaring it as 'the most excruciating evening I ever spent in all my life. I hope I shall never have to attend another like it'. Another critic, although a recognized admirer of the ultramodern set, was visibly overcome by Toccata Tragica, and was forced to put his fingers in his ears. However, it was Agnew's Dance of the Wild Men that came in for the most blistering attack:

\begin{abstract}
'Wild Man's Dance' was certainly atmospheric. It was very wild. I think you would get something near the effect if you put somebody who knew how to leave discords unresolved, but whose fingering on the piano was not too facile, to play chords at the bass and treble, and then to sit on the middle of the piano, repeat the chord playing and sit on the treble, again repeat the chords and sit on bass, middle and treble. In fact, I have heard it done that way, I won't say by whom or where, and it sounded quite impressive. ${ }^{1}$
\end{abstract}

Agnew had told the Lone Hand in 1920 that he had bcen forced to abandon the limitations of key and tonal relationship: an extraordinary statement indeed. ${ }^{2}$ In 1923 he declared Scriabin's ninth sonata 'wonderful', and, in his defence against the charge of musical Bolshevism, professed a deep admiration for the music of Stravinsky. ${ }^{3}$ The charge of 'ultramodern extravagance' sets Agnew apart from his fellow Australian composers. Whereas it was acceptable to be 'modern', to be 'ultramodern' was not. In Britain and Australia, this term had the power to signal a transgression beyond the respectable; Agnew's music was scandalous.

1 'Allegro Guisto', 'Ultramodern Extravagance', Australian Musical News [hereafter AMN] 10/12 (1921), 494.

2 F. Gordon, 'Roy Agnew-Composer', Lone Hand (1920), 29.

3. 'Australia's "Stravinsky": Roy Agnew Interviewed', $A M N 12 / 7$ (1923), 311. 
Forty-two years later, Roger Covell identified the audible hissing that broke out after the performance of Larry Sitsky's provocatively hard-edged Woodwind Quartet at a 1963 Hobart Convention as a turning point in Australian musical history. It was, he wrote, 'like the breaking of a long drought of indifference. For once an Australian composer was being listened to with an emotion stronger than polite apathy'. "The concert that prowoked the scathing review, 'Ultramodern Extravagance', had occurred over forty years carlier. Covell was unaware of it. On the contrary, readers of Covell's classic work, Australia's Music: Themes of a New Society, will find a harsh appraisal of Agnew's music: its dense, fuzzy homogenous language, he mused, made anything more than a small dose of it seem like a surfeit of clotted cream, ${ }^{5}$ For Covell, Agnew was part of a pre-war generation of Australian composers who were irremediably 'second-hand', a 'by-product of the unavoidably provincial nature of Australian society. ${ }^{6}$ The general tenor of Covell's book is captured in the second part of its title: Themes of a New Society. In his enthusiastic embrace of his own generation as the first to engage with modernism he essentialized what came before to emphasize the contrast. Perceiving previous composers as too close to Britain and Empire, Covell did not place the music in its historical context, betraying what has emerged as a general tendency in Australian musical history towards ahistoricism, whereby music is interpreted or judged on current aesthetic standards rather than the ones prevailing when the work was written. This approach was very much of its time. ${ }^{8}$ As Joel Crotty pointed out in 1994 in a welcome reassessment of Australian musical historiography, Covell was the voice of his generation: one of the 'young Turks', who, as Crotty remarks, felt that 'for the first time they were joining the international stage: 9 The music of previous generations was rejected as 'un-Australian'; the pre1960 s was Australia's musical 'Dark Ages'.

Almost forty years later, this assessment is still very much alive. Covell's version of events stands as the only available generalist natrative musical history. Geoffrey Serle used Covell's book as his main source for his history of Australian high culture From Deserzs the Propbets Come (1973), in which music is deemed the laggard in the arts', even, as late as the 1940 s, 'rather more a phantom than a fact: ${ }^{10}$ In 2002, Adrian Thomas referred to the 'belated arrival of musical modernism' which coincided, he asserts-apparently oblivious to the suggestion of cultural cringe - with the appointment of English conductor and administrator

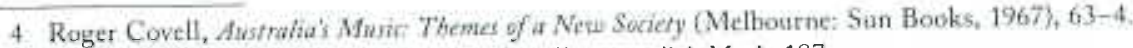
For an account of this performance see Covell, Australia's Music, 187.

5 Covell, Australia's Music, 157.

6 Ibid., 143.

7 See the chapter 'Creative Development', in Covell, Australia's Music, 141-234.

8 Covell's book appeared in 1967, taking its place alongside other cultural histories such as $\mathrm{H}$. M. Green's work on literature, Asumatian Literature 1900-1950 (CuAton, Vic: Melhourne University Press, 1951), Bernard Smith's on painting. Autralian Painting Today (St Lucia: University Of Qpeensland Press, 1962) and J.M. Freeland on architecture, Architerdate in Aastrafia: A History (Melbourne: Cheshire, 1968) in what Hsu-Ming Teo and Richand White have identified as the 'radical nationalist tradition in cultural history'. See Hsu-Ming Teo and Richard White, Cultural History in Ausiralia (Sydney: UNSW Press, 2003), 16.

9 Joel Crotty, 'Interpreting Austratian Music History: A Qucstion of 'Time, Place and Atrituides', Sounds Australian 41 (1994), 7.

10 Geoffrey Serle, The Crative Spirit in Australia A Culitural History, rev, ed. (Melbourne: William Heinemann Australia, 1987), 79
John Hopkins as $\mathrm{t}$ fewer than seven $r$ Companion to $M u$ McNeill also ung Australian symph restatement of the when he wrote th Meale and Nigel? out of its English

Earlier, during reassessment of $\mathrm{A}$ ination, an impor1 Sitsky has been Australian musici music: a body of 1 mercial purposes, the latter, in par engagement witk musical language maybe even Schc had, except whet English pastoral and Busoni'. ${ }^{16}$

In the same 'arrived' in Aust 1950 s and 1960s, ticularly jazz, no called tradition Australian music important, his as bastion of nineter overlooks those, tion of contempr

11 Adrian Thoma Hopkins Era',

12 David Symons Music and Dan House in assoc

13 Rhodcrick Mc www.usq.edu.:

14 Martin Buzace

15 Larry Sitsky," Manuscript: $N$ Campbell, Rol Series; No. 9.1 66-7.

16 Ibid., 67.

17 Bruce Johnsor Brown et al., (

18 Ibid., 247. 
John Hopkins as the ABC's Federal Director of Music in $1963 .{ }^{11}$ There are no fewer than seven references made to the 'English pastoral legacy' in the Currency Companion to Music and Dance published in 2003,12 and in 2004, Rhoderick McNeill also unquestioningly accepted this interpretation in his work on the Australian symphony of the $1950 \mathrm{~s}^{13} \mathrm{~A}$ very recent and perhaps most pithy restatement of the Covell thesis was expressed by Martin Buzacott in June 2006 when he wrote that the 1960s generation composers, Peter Sculthorpe, Richard Meale and Nigel Butterley 'took Australian music by the throat and wrenched it out of its English pastoral stupor'. ${ }^{14}$

Earlier, during the mid-1990s, there had been a call, albeit a limited one, for a reassessment of Australian music history. A year after Crotty's cry for a re-examination, an important collection of essays co-edited by Larry Sitsky was published. Sitsky has been the major figure in bringing Agnew's music back into the Australian musical consciousness. He identifies two distinct streams in Agnew's music: a body of music written in a conventional idiom for pedagogical and commercial purposes, and a more challenging and complex style. Sitsky was drawn to the latter, in particular, the six piano sonatas, for their cosmopolitanism and engagement with contemporary European music. He recognized in Agnew's musical language an 'affinity with Scriabin, Scott, Bridge, Ireland, Ravel and maybe even Schoenberg.' ${ }^{15}$ For Sitsky, Agnew was a like-minded precursor who had, except when he had to earn his bread and butter, also eschewed the 'safe English pastoral style' for the 'more difficult path derived from Liszt, Scriabin and Busoni'.16

In the same volume, jazz historian Bruce Johnson argued that modernism 'arrived' in Australia far earlier than assumed, in the late 1910s rather than the 1950 s and 1960s, but that its mode of travel had been through popular music, particularly jazz, not art music, and for this reason had been overlooked by what he called 'traditional musicology'. 17 Although his demand for a rethinking of Australian music history by including musics other than art music was timely and important, his assessment that early twentieth-century Australian art music was 'a bastion of nineteenth-century assumptions: conservative, patriarchal, Anglocentric' overlooks those, such as Agnew, who were active in the consumption and production of contemporary art music. ${ }^{18}$

11 Adrian Thomas, "The Climate of Change: The ABC as Patron of Australian Music During the Hopkins Era', Australasian Music Researcb 7 (2002), 47.

12. David Symons, Joel Crotty, John Whitcoak, 'Composing Music', in Currency Companion to Music and Dance in Australia, ed. Aline Scott-Maxwell and John Whiteoak (Sydney: Currency House in association with Currency Prcss, 2003), 164-8.

13 Rhoderick McNeill, 'The Australian Symphony of the 1950s', (2004), available from http:// www.usq.edu.au/resources/australiansymphonicsofthe1950s.pdf.

14 Martin Buzacott, 'Commission Impossible', Limelight (June 2006), 20.

15 Larry Sitsky, 'The Piano Sonatas of Roy Agnew: Some Personal Musings', in One Hand on the Manuscript: Music in Australian Cultural History 1930-1960, ed. Nicholas Brown, Peter Campbell, Robyn Holmes, Larry Sitsky and Peter Read, Humanities Research Centre Monograph Series; No. 9. (Canberra: Humanities Research Centre, Australian National University, 1995), 66-7.

16 Ibid., 67.

17 Bruce Johnson, 'Towards a New Cartography: Rethinking Australia's Musical History', in Brown et al., One Hand on the Manuscript, 243-57.

18 Ibid., 247. 
Of course Covell was not the first to fall prey to Australia's problem. with cultural cringe. Rather, he was following an already rich tradition begun many decades earlier. The condescension and dismissive remarks made by leading British artists and intellectuals hit like-minded Australians hard. They took to heart for instance D.H. Lawrence's less than positive remarks made in 1922, only a year after 'Ultramodern Extravagance'. It was a land, Lawrence complained, of 'beastly little suburban bungalows' inhabited by 'healthy but hollow people' who were 'vaguely and meaninglessly on the go'. He did not hold back in a letter to his sister: 'You never knew anything so nothing, Nichts, Nullus, niente, as the life here'. ${ }^{19}$

The tone of these remarks and the implication that Australia's cultural backwardness, its geographical remoteness and its lack of originality as a transplanted culture, was an irreversible state caused many Australian intellectuals a deep sense of anxiety. Public intellectuals and literary figures from the 1930s, such as P.R. Stephensen, were not alone in their efforts to address these concerns. ${ }^{20}$ There were those in the highbrow musical minority who were publicly grappling with these anxieties from the late '20s onwards. These included Keith Barry (energetic champion of Agnew, editor of the Musical Australia and Programme Controller for the ABC), George de Cairos Rego (early President of the NSW Musical Association who, in the early twenties, kept the Daily Telegraph readership wellinformed of the most up-to-date musical developments) and Thorold Waters (editor of the $A M N$ from 1923 into the 1940s). ${ }^{21}$

The objective of the present article is to question the received wisdom about Australia's music history by rethinking the early work of Roy Agnew and its context. My approach is twofold. Firstly, I will argue that early works, in particular Dance of the Wild Men (1919) and Poem no. 1 (1920), belong in the world of centric music with attenuated ties to functional tonal harmony and suggest similaritics in compositional approach in the first instance to the Russian Futurist, Leo Ornstein, and in the second to the Russian mystic, Scriabin. This music takes its place alongside other early twentieth-century Western music, music characterized by Jim Samson as 'transitional'. ${ }^{22}$ I will then look at Sydney in the late 1910 s and early '20s looking for a cultural field, to use Bourdieu's concept, that could provide access to modern music, in particular that of Ornstein and Scriabin, and that could explain the significant change in compositional style from Agnew's first publication in 1913, the naive and conventional Australian Forest Scenes, to the work he produced at the end of the decade. This is a fundamentally different picture of our musical past, one that reveals an engagement with the most recent musical developments over 'there. ${ }^{23}$

19 Cited in Deidre Coleman, 'Grand Tours: Lawience's Novel View of Down Under', Independent, 26 January 2002, available from www.travel.indepentent.co.uk/ausand pacific/articlc200347.ece.

20 For an exploration of many of these anxieties see P.R. Stephensen, The Foundations of a Culture in Australia: An Essay Towards National Respect (Sydney: Allen \& Unwin, 1986).

21 The growing concern with Australia's cultural belatedness is played out throughout Waters's own editorials for the $A M N$ from the mid-twenties and into the forties. $\Lambda \mathrm{n}$ article on Thorold Waters's faulty memory is a work-in-progress.

22. See Jim Samson, Music in Transition: A Study in Tonal Expansion and Atonality 1900-1920 (London: Dent, 1977).

23 Crotty was the first to historicize Covell and his work (see note 9). Malcolm Gillies has also questioned the generally accepted assumption that 'nothing much happened in Australian music before its miraculous "birth" one weekend in 1963, in Hobart'. See Malcolm Gillies, 'Australian Piano Music of the Twentieth Century', Sounds Australian 68 (2006), 39.
Agnew was regars 1960 he was 'clotted c a totalizing concept o ernisms, freed from include the vernacule the problematic natus told $u s$ in a recent $r e$ Using as an example modernism Lluís D pottery roses, each th works that no longer call themselves mor matched up with $D$ idea of modernism. ${ }^{2}$ among recent studit movement and the $n$

Part of this resha tury music which $\mathrm{Ci}$ transitional or, as it standing of the mu: developed new way concerned with nor experimentation an visual, lingual or $\mathrm{m}$ tional languages. $T$ of influence that $\mathrm{cr}$ tural field that led

The reshaping $c$ tice and the search more inclusive ph beyond tonality fo composers from $t$ extreme atonal mu Casella, Szymano' world renders it $m$

Numerous tran: can, to some exten come to be known tres around a part musical space; to characteristics of common interval pitch material. Th Roslavets's syntber increasingly self-I determinant' wen

24 Robert Hughes, co.uk/features/st 
with culany decig British heart for ily a year f'beastly who were his sister: re. 19

ral backisplanted sep sense 1 as P.R. 20 There ing with nergetic ontroller Musical iip wellWaters

$n$ about its conrticular Ecentric rities in rnstein, ts place ized by 10 s and ld prond that i's first to the nt picrecent

Agnew was regarded as transgressively ultramodern for 1920s Sydney, but by 1960 he was 'clotted cream'. Readings of modernism have shifted dramatically from a totalizing concept of modernism to a more pluralist and nuanced concept of modernisms, freed from the focus, positive or negative, on formalism and system to include the vernacular and decorative. Robert Hughes deftly and wittily captured the problematic nature of modernism as a general aesthetic term. 'Modernism is', he told us in a recent review, 'a weasel of a word, whose meanings slip and slide.... Using as an cxample the Palace of Catalan Music, by the star architect of Catalan modernism Lluís Domenech, with its ceiling 'encrusted with giant polychrome pottery roses, each the size of a cabbage', Hughes concluded, 'once movements and works that no longer seem to match up with modernism as we understand it used to call themselves modernist'. He added importantly that neither would it have matched up with Domenech's northern contemporaries Gropius and Corbusier's idea of modernism. ${ }^{24}$ The same can be said of Agnew. This study takes its place among recent studies of modernism that recognizes the stylistic diversity of the movement and the need for early modernisms to be better historicized.

Part of this reshaping of modernism includes the body of early twentieth-century music which can be understood as transitional. A general understanding of transitional or, as it is also known, post-tonal music, is critical for a richer understanding of the music of Agnew. A wide range of composers, artists and writers developed new ways of hearing, looking, perceiving and thinking. They were concerned with novelty, difficulty, the desire and ability to shock, an interest in experimentation and innovation, the fragmentation of existing syntaxes whether visual, lingual or musical, the search for new vocabularies, the reshaping of traditional languages. These shared interests and inclinations created a general sphere of influence that could be understood as an international and transnational cultural field that led artists in widely dispersed places to similar conclusions.

The reshaping of traditional languages signalling a break with common practice and the search for alternatives to, or redefinitions of, tonality was a wider and more inclusive phenomenon which preoccupied many composers. This move beyond tonality found different modes of expression among a range of diverse composers from the radical athematicism of Schoenberg and Webern's most extreme atonal music to the music by, to name a few, Stravinsky, Bartók, Scriabin, Casella, Szymanowski, Baines and Debussy, whose connection with the tonal world renders it more familiar. Agnew belongs to this latter group.

Numerous transitional works resist rigid classification as tonal or atonal; many can, to some extent, exist in both the tonal and non-tonal worlds. This music has come to be known as centric; although not functionally tonal, it nonetheless centres around a particular pitch or tonal centre. Many composers sought a unity of musical space; to develop a harmonic language consistent with the intervallic characteristics of the melodies. Harmony and melody were derived from a common interval source and become two different ways of presenting the same pitch material. Think for instance of Casella's objet sonore, Scriabin's mystic chord, Roslavets's synthetakkord and Busoni's 'invented scales'. Post-tonal works became increasingly self-referential. The elevation of the motive as a prime 'structural determinant' went hand in hand with this interest in unifying the horizontal and

24 Robert Hughes, 'Paradise Now', Guardian, 20 March 2006, available from http://arts.guardian. co.uk/features/story/. 
vertical aspects of music. With the dismantling of traditional functions, dissonance was freed to varying degrees from its tonal obligation to resolve to consonance. The removal of goal-directedness leads to static harmonic complexes that do not need to go anywhere. The result is an altogether different sound world that allowed the principle of transposition to become an important compositional technique. This figures in much of Scriabin's music where it took over from diatonic relationships, but also informs the chord parallelism of Debussy, Busoni and Szymanowski and Agnew's approach to formal structure.

\section{Abandoning the Limitations of Key and Tonal Relationship}

\begin{abstract}
A gifted instrumentalist was observed standing in a corner leading to the artist room, looking quite ill and with his hands over his ears. He said it was the siren of a Balmain ferry boat that he had just heard, and that he could not establish its relationship, as he was unable to determine the key of the Dance of the Wild Men. ${ }^{25}$
\end{abstract}

Given his pained reaction the anonymous instrumentalist probably erred in attending Roy Agnew's 1923 farewell concert. His reaction to the music indicates that Agnew in this work had moved beyond tonality. The gifted instrumentalist was correct. Even without the blast of the ferry siren, I too am unable to determine the key of Dance of the Wild Men. My analysis of this work, and the Poem no. 1, will attempt to answer the question of how these 'tonal limitations' have been overcome.

The absence of a key signature in music from this period is telling. It indicates a distance from tonality and suggests that the music, rather than being in $\mathrm{C}$ major or A minor, is in fact not conceived of as being in a key at all. This is certainly the case with Agnew's six Poems published between 1922 and 1927, many of his seven preludes, and at least three of the six sonatas. It is also true of his exuberant, unashamedly rambunctious work Dance of the Wild Men written in 1919. This work, along with Deirdre's Lament and his Toccata tragica (also known as Poème tragique), caught the ear of the visiting pianist, Benno Moiseiwitsch. Moiseiwitsch's inclusion of these three works in his Sydney concerts of 1920 brought Agnew his first real fame and notoriety in Australia, as well as his first English publications. Dance of the Wild Men was published in 1922 by Chester, an English company recognized for championing 'ultra-modern' music. From 1915 the firm had entered into contracts with such composers as Casella, Falla, Malipiero, Poulenc and Stravinsky as well as the Englishmen Bax, Berners, Goossens and Ireland.

Ostensibly, the composition's conventional and familiar rhythmic patterning and homophonic texture, as well as recurrences of melodic and harmonic ideas, establish a deceptive feeling of normality. ${ }^{26}$ However, on further analysis it becomes evident that despite there being audible arrival points in the music there are no underlying harmonic progressions or obvious cadential points that clearly identify the key of the piece. Musical continuity and coherence occur outside the framework of tonal function.

25 'Roy Agnew Farewell', AMN 12/12 (1923), 17 (emphases added).

26 Samson, Music in Transition, 178.
Example 1 Openin

The dissonanc Agnew is thinkir linear aspects of $t$ a minor second, characteristic inte parallel chromati The dissonance between bottom with the idea of support in an att

In a general se through juxtapos distinction betwi of the compositic out the opening An examination

In an intensel repeated, riding until it is broken from b. 7 is form metrically displa niment does not enth below its is material informs is now highlighı only to be inter ning a semitone establishes a ten Ab/A starting a semitone higher

Coherence is ple, the startlin expansive and $\mathrm{s}$

Both share 1 phrase of sectio theless, the inte 


\section{Fiercely with the utmost intensity}

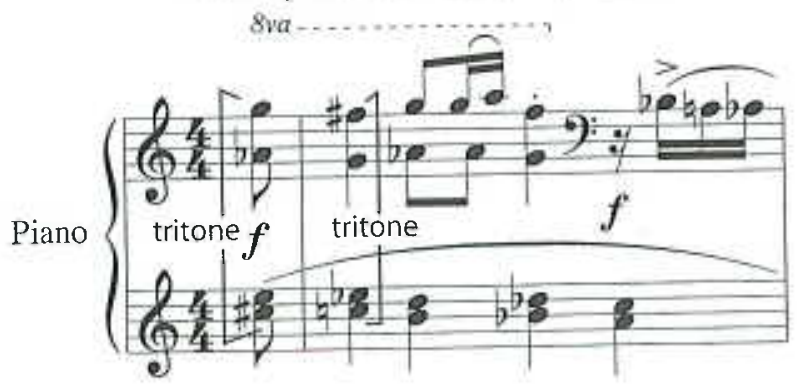

Example 1 Opening of Dance of the Wild Men, b.1

The dissonance of the opening bars is not only striking, it also shows that Agnew is thinking intervalically. Certain intervals inform both the vertical and linear aspects of the piece. The linear motion of the opening motive is made up of a minor second, a major second and a minor third. These intervals provide the characteristic intervallic material for the whole piece. It is supported vertically by parallel chromatic major sevenths in the right hand and minor thirds in the left. The dissonance of the opening two chords is sharpened by the tritone span between bottom and top. Agnew is experimenting, as did Scriabin and Bartók, with the idea of using the same intervals that make up the melody as harmonic support in an attempt to unify the musical space.

In a general sense the contrast between the main sections $\mathrm{A}$ and $\mathrm{B}$ is achieved through juxtaposing chromaticism with a kind of modal writing. However, the distinction between chromaticism and modality that signals the larger divisions of the composition's formal sections is found at play at a more local level throughout the opening section. It creates an expectation for the appearance of section B. An examination of the first thirteen bars reveals this interplay.

In an intensely chromatic opening, the introductory phrase and its answer ate repeated, riding above an ever-descending chromatic bass line of minor thirds, until it is broken off by an ascending chromatic flourish. The subsequent phrase from b. 7 is formed from a B-scale on $\mathrm{E}$. The second phrase reappears at $\mathrm{b} .9$ now metrically displaced to just after the downbeat of the bar. Although the accompaniment does not depart from its chromatic motion, it appears now a major seventh below its initial appearance. (Another example of how the basic intervallic material informs the musical fabric.) Bar 11 invokes the modality of bb. 7 to 9 but is now highlighting the $\mathrm{B}$ b using what could be understood as an F-scale on $\mathrm{B}$; , only to be interrupted again by the now familiar figure in bb. 12 and 13 beginning a semitone lower on the A. The chromaticism that saturates the surface also establishes a tension based on semitone slippage such as that between $D, / D$ and $\mathrm{A} b / \mathrm{A}$ starting at b. 14. The appearance of the theme of the second section is a semitone higher than the opening $\mathrm{G}$.

Coherence is also created in the tightly knit motivic relationships. For example, the startling and nervous opening phrase is found later in an altered, more expansive and stable form in the modal second section.

Both share the all important semitone and descending minor third. In the phrase of section B the shape of the opening three notes has been inverted; nonetheless, the interval of the semitone is retained and both end with a falling minor 


\section{Dance of the Wild Men}

Fiercely with the utmost intensity About $\cdot=176$
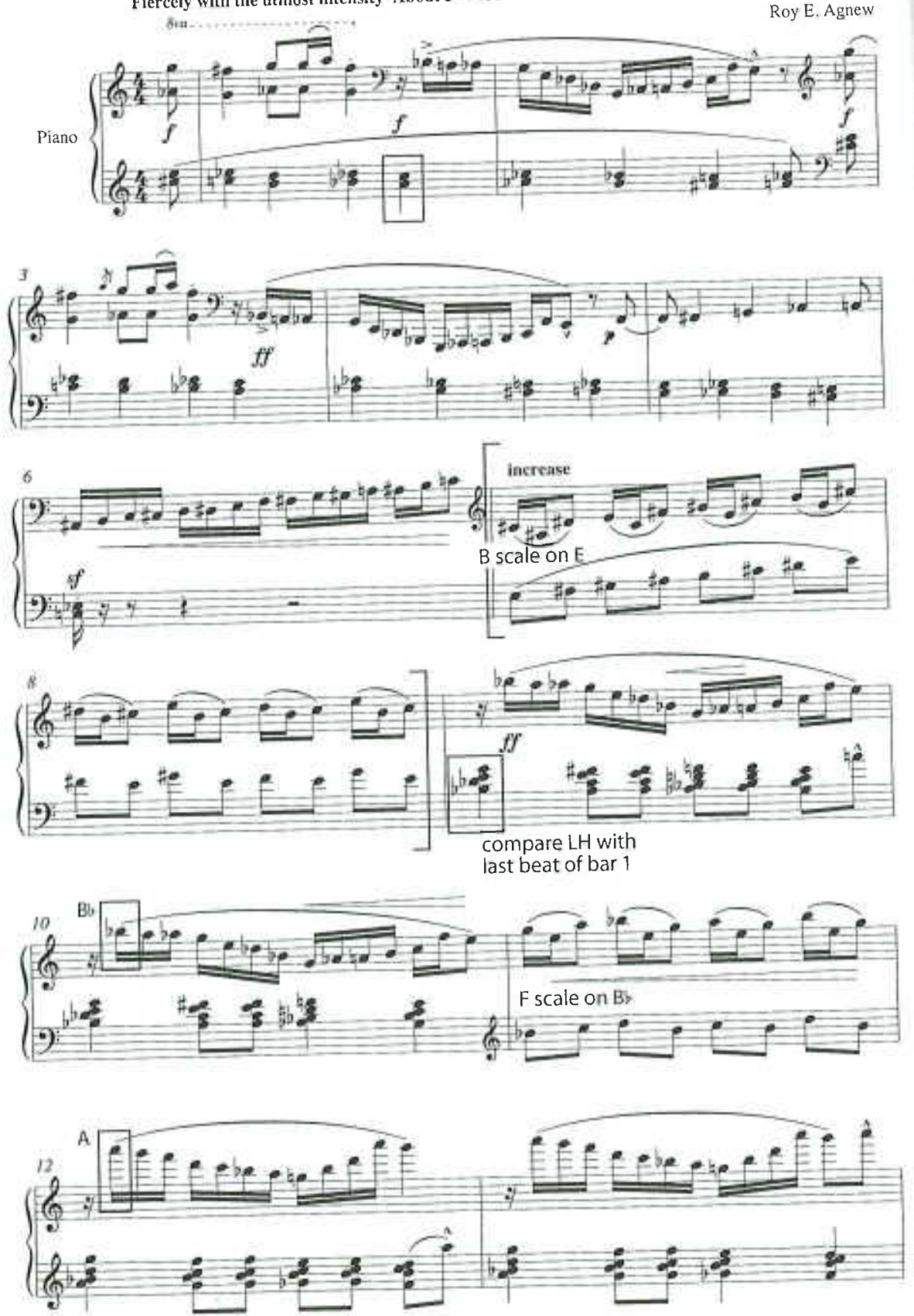

Example 2 Juxtaposition of chromatic and modal writing, bb. 1-13
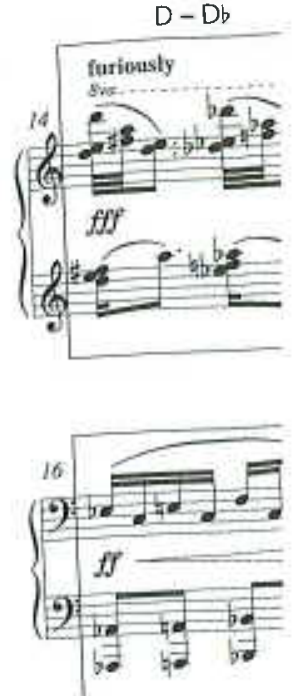

Example 3 Semitor

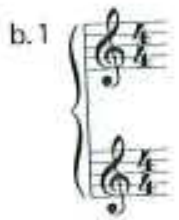

alt

bb. $29-30$ $\left\{\begin{array}{l}6: \div \\ 9: 4\end{array}\right.$

$\frac{2}{9}$

Example 4 Corr 29-30 

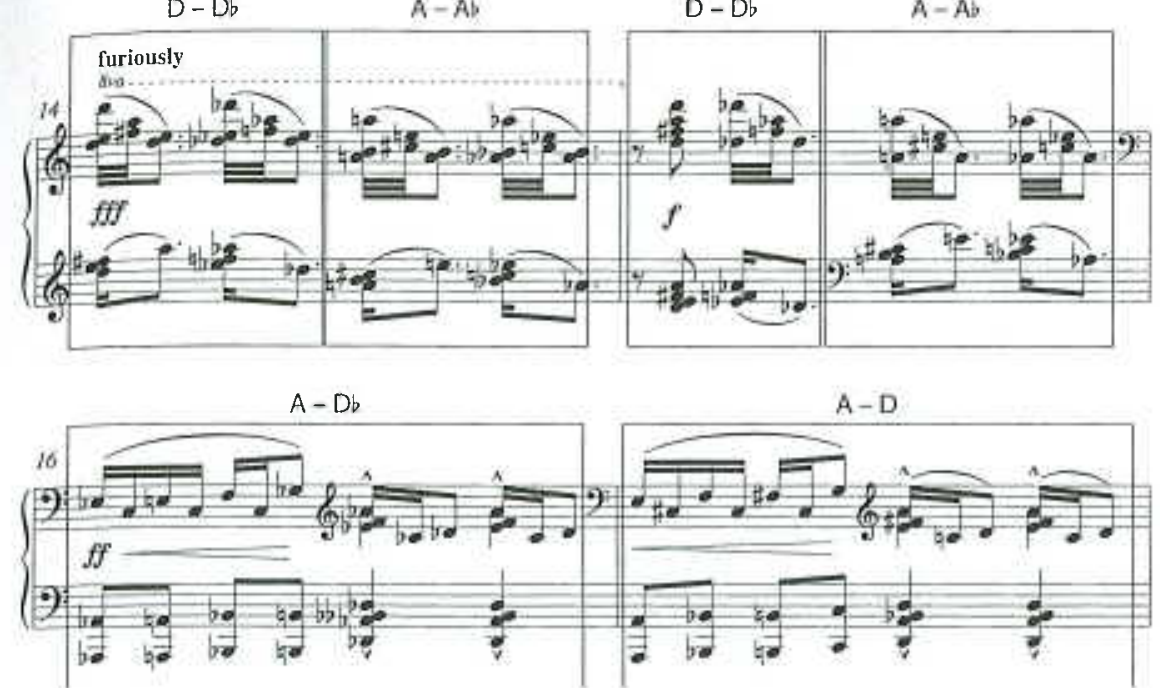

Example 3 Semitone slippage between $D-D_{b}$ and $A-A_{b}$ bb. 14-17

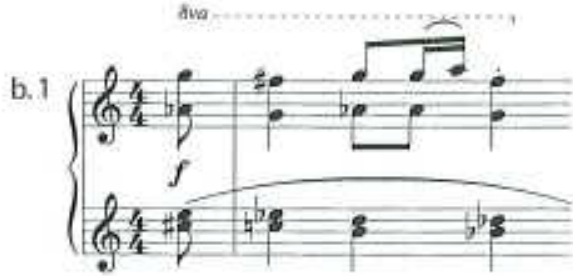

bb. $29-30$

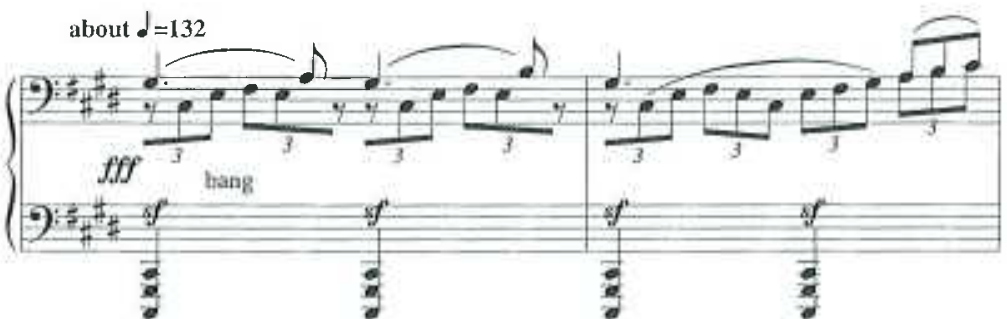

opening b. 1

section B opening bb. $29-30$

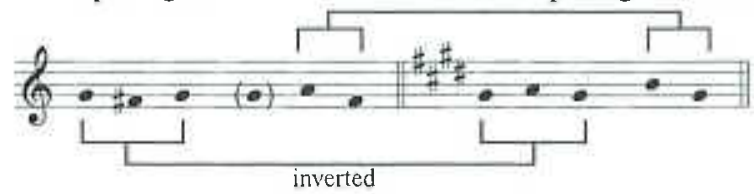

Example 4 Comparison between the opening bar and the opening of Section B, b. 1 and bb. 29-30 
bars $1-4$
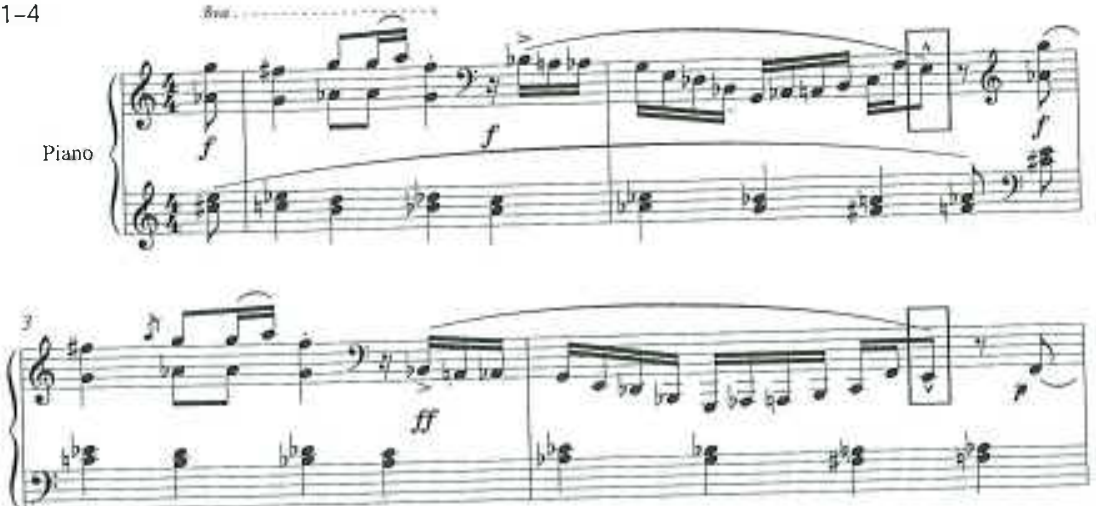

bars $7-8$

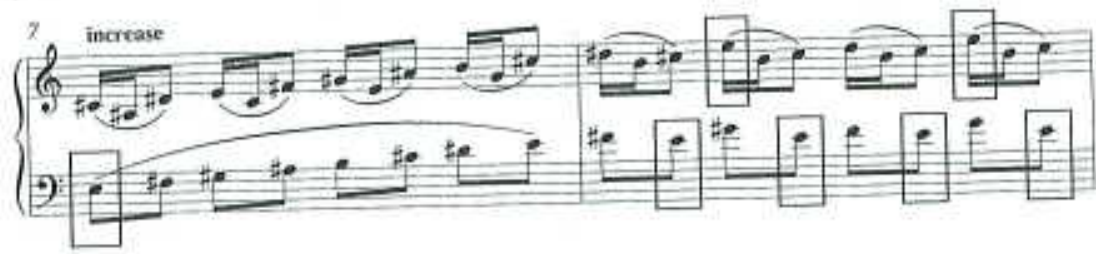

bars $19-20$

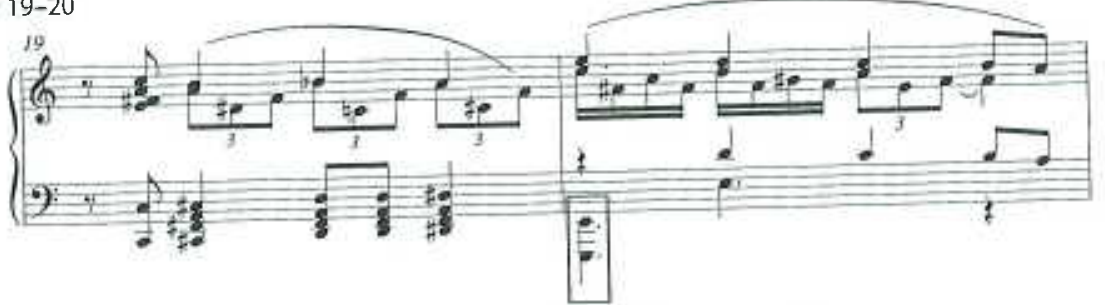

bars 24-25

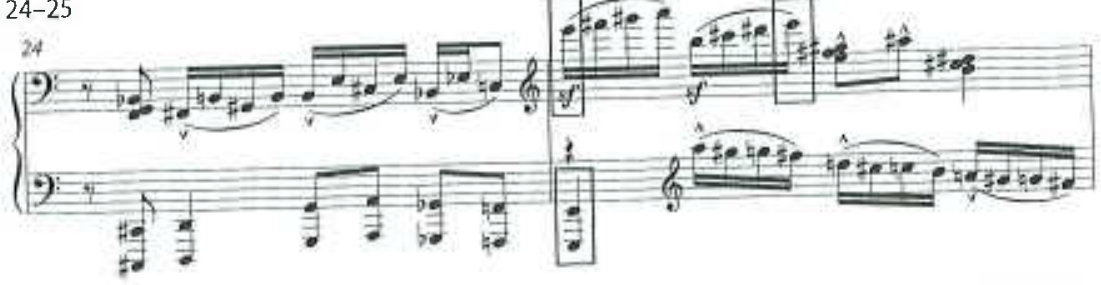

Example 5 Transition from $E$ as prioritized pitch to tonal centre, bb. 1-4, 7-8, 19-20 and 24-25

third, one can hear the similarity between the two phrases. Although this kind of motivic relationship can be found in earlier music, the way this is connected here, via a three-note shape or contour that is to be found throughout, is perhaps of more importance. It gives the piece its characteristic sound and provides a strong sense of continuity

Although this music is not functionally tonal, it is diatonic and has certain centric qualities. From the outset, priority is given to the pitch E. Initially it is foregrounded only in the melodic line, where it appears twice as an emphatic and obvious arrival point after a chromatic gesture. It is then highlighted as a more section

bars

tonal centre

Figure 1 Major pitch C

general goal in the are satisfied when occurs at b. 20 on a passage that begins From its beginning centre later on in tr

As the piece unf emerge as particula

However, the pi approaches to these tional: in both cas Agnew rather crud

There is contini tion (bb. 20-28) c evokes the relative revolving around a sion. The E major progression or obr point is by nature section goes nowl The fact that the compounds the ar approached by a 1 times as a kind of tion. It is frenetic too, the second pa from a simple fee

The instructio direction of ffffff caused jaws in th was challenging. an 'Australian Stı as barbarous and primitivism. In $f_{i}$ roboree, on the 


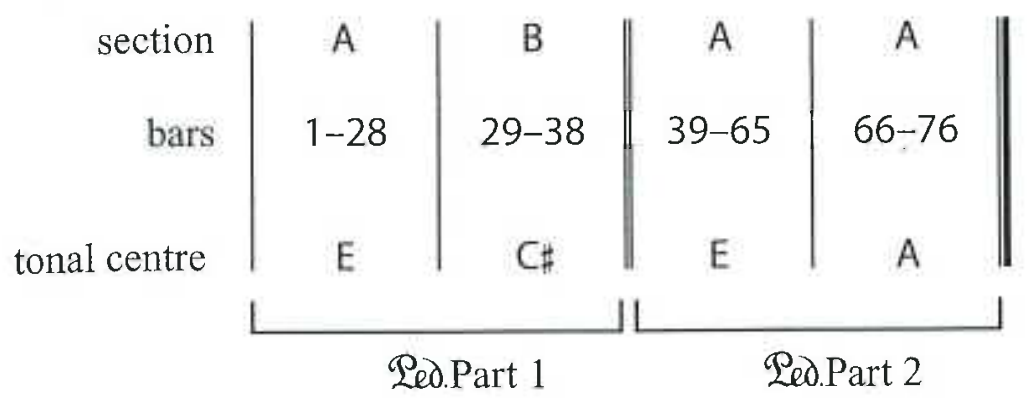

Figure 1 Major pitch centres outlining an A major triad

general goal in the modal writing of bb. 7 and 8 . These preliminary indications are satisfied when the first really obvious harmonic landing point of the work occurs at b. 20 on a low and loud E octave and again at b. 25. This introduces the passage that begins the inexorable transition to the next section nine bars later. From its beginnings as a prioritized pitch, E ultimately transforms into a tonal centre later on in the section.

As the piece unfolds, the pitches $\mathrm{E}, \mathrm{C} \#$ and $\mathrm{A}$, which are heard as $\mathrm{E}-\mathrm{C} \sharp \mathrm{E}-\mathrm{A}$, emerge as particular centres outlining an A major triad.

However, the piece is not 'in $A$ ', in the sense of being in $A$ major or minor. 'The approaches to these two parts, in which $\mathrm{C}_{\#}$ and $\mathrm{A}$ are centric pitches, are not functional: in both cases the chromatic approach is the same, but the second time Agnew rather crudely adjusts the final four notes to facilitate the arrival on the A.

There is continuity in the shared pitch material between the end of the A section (bb. 20-28) centred around $\mathrm{E}$, and the $\mathrm{B}$ section centred around $\mathrm{C} \sharp$. This evokes the relative minor relation but in actuality they are merely the same pitches revolving around a different centre with no trace of functional harmonic progression. The $\mathrm{E}$ major triad is the dominant of $\mathrm{A}$, but there is no sense of harmonic progression or obvious voice leading that would clearly establish a key. A pedal point is by nature static and, once the arrival on the pedal point is established, the section goes nowhere harmonically until Agnew slips back into the first section. The fact that the pedal lacks the third of the triad, leaving its quality unclear, compounds the ambiguity. These $\mathrm{B}$ sections are characterized by harmonic stasis, approached by a mad confused frenzy of chromaticism. Section $A$ is heard both times as a kind of breathless unstable, chromatic upbeat to the more settled B section. It is frenetic motion moving to a place of unstinting sameness. Rhythmically too, the second part is more stable. The shift is heightened by the rhythmic change from a simple feel to a compound feel.

The instructions to play 'furiously', even to 'bang', and the final extreme dynamic direction of ffffff produced music whose extremes of violent emotion and volume caused jaws in the Sydney audience to drop. The music's sheer ferocity and attack was challenging. As a result, Agnew was labelled an ultra-modernist, a Bolshevik, an 'Australian Stravinsky'. Dance of the Wild Men engages with the idea of the exotic as barbarous and this piece could be understood as an early instance of Australian primitivism. In fact, the work has long since been regarded as a depiction of a corroboree, on the basis of a passing reference in the $A M N$ uncorroborated by the 

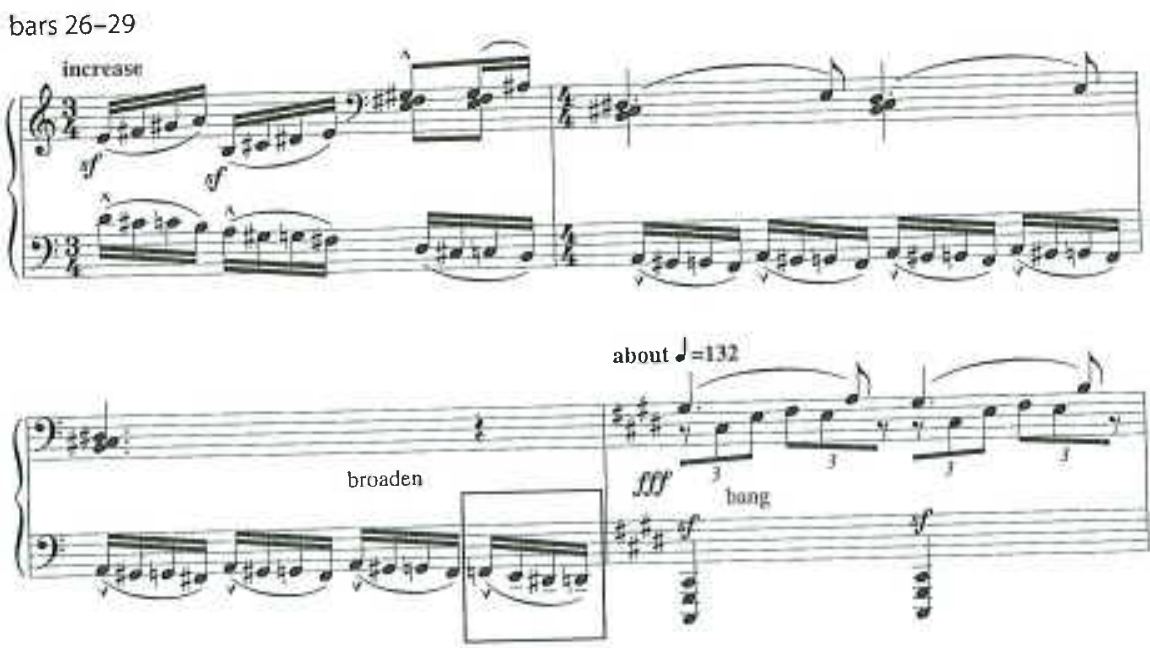

bars $63-66$
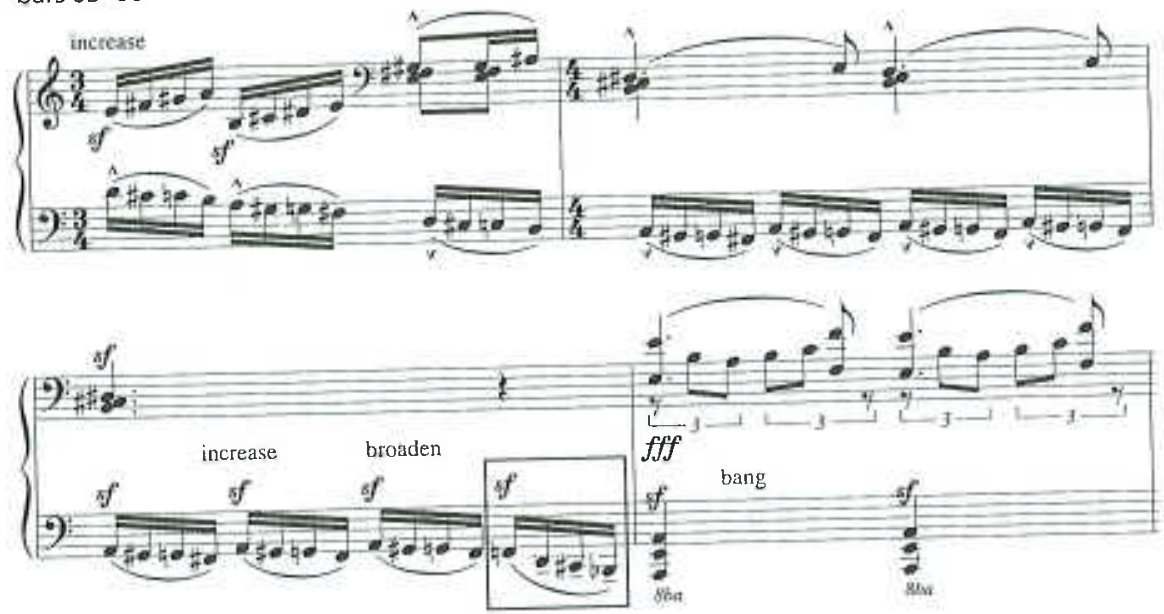

Example 6 Non-functional approaches to Section B, bb. 26-29,63-66

composer. ${ }^{27}$ I suggest an alternative claim for the work's provenance, one that does not impinge upon this more 'nationalist' understanding but can easily coexist alongside it. Whereas the piece may or may not essay white depictions of indigenous Australia, it is directly connected with Ornstein. This proposition also helps to account for a prominent feature of the work: the dirtying up of quite simple triadic structures and other patterns with added notes as found in bb. 14-17 and 25-26. A cluster-like effect is created when played at the indicated speed.

In 1920, in the chic new lifestyle magazine Tbe Home, George de Cairos Rego, a friend of Agnew and the dedicatee of his ever-popular Rabbit Hill, reviewed Harriette Brower's book Piano Mastery (1917). Brower's interview with Ornstein, the originator of cluster technique, was singled out for detailed discussion in

27 'The Modernism of Roy Agnew', AMN 21, (1931), 14.

bars 14-17
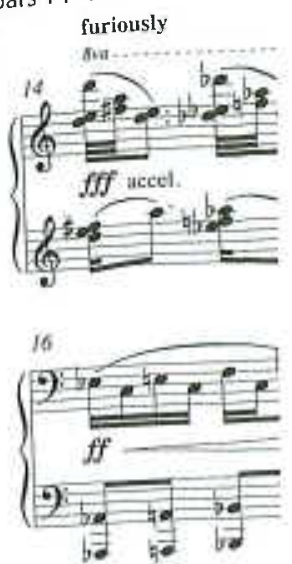

bars $25-26$

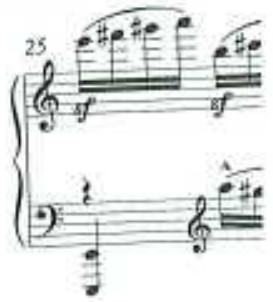

Example 7 Cluster-1

Cairos Rego's revi includes a long de Wild Men's Dance. ates this piece: 'I former depresses above them'. ${ }^{28} \mathrm{Ag}$ not have seen or 1 what he had possi

Whereas readi Dance of the Wild vasive. The prese from this decade 1922 in Australi; sense of tonal cer

Like Dance of (A"). The seconc

28 Harriette Brow York: Frederick

29 Frances Gordor 
bars $14-17$
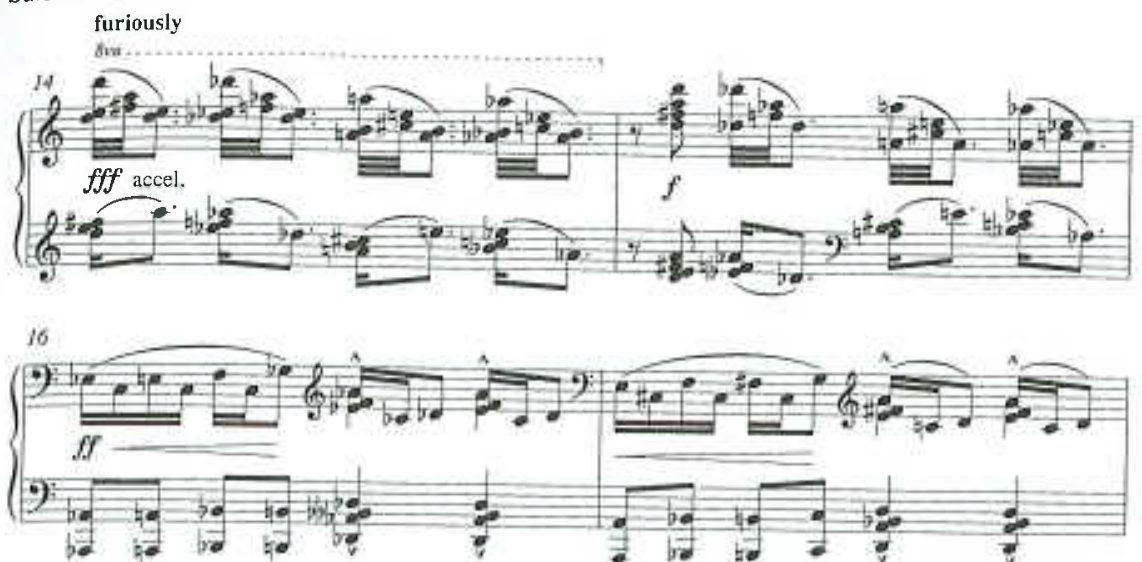

bars $25-26$

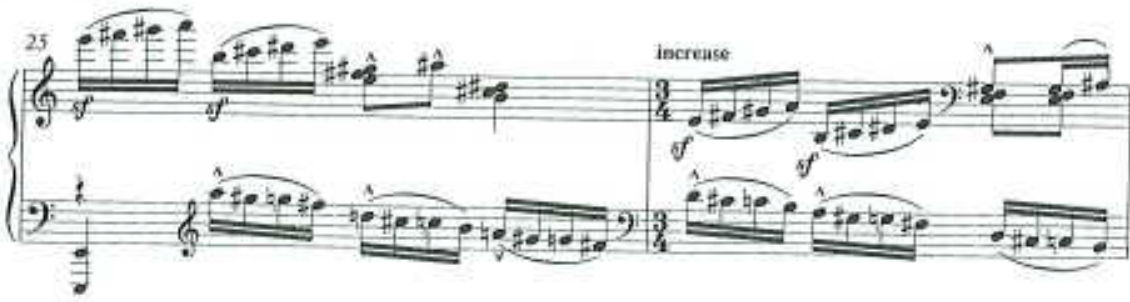

Example 7 Cluster-like effects à la Ornstein, bb. 14-17, 25-26

Cairos Rego's review which we may assume Agnew was aware of. That chapter includes a long description of Ornstein's own work Danse Sauvage also known as Wild Men's Dance. Ornstein told Brower about the cluster technique that permeates this piece: I must here use a palm of my hand as well as the fingers; the former depresses the white keys below, while the fingers touch the black keys above them'. ${ }^{28}$ Agnew's clusters are a less extreme version of Ornstein's. He need not have seen or heard Ornstein's Wild Men's Dance to experiment sonically with what he had possibly only read-in effect translating words into sound.

Whereas reading about Ornstein may have influenced Agnew's approach in Dance of the Wild Men, Scriabin's influence was generally more powerful and pervasive. The presence of late Scriabin is strongly felt in many of Agnew's pieces from this decade. One such work is his beautiful little Poem no. 1 published in 1922 in Australia by Allans. ${ }^{29}$ As with Dance of the Wild Men there is no strong sense of tonal centre in Poem no. 1.

Like Dance of the Wild Men, this work is structurally straightforward: AB A'B' $\left(A^{\prime \prime}\right)$. The second section itself is derived from material of the first. The second

28 Harriette Brower, Piano Mastery: Talks with Master Pianists and Teachers (Second Series) (New York: Frederick A. Stokes Company, c. 1917), 190-1.

29 Frances Gordon refers to this Poem in her article of 1920 , two years before its publication. 


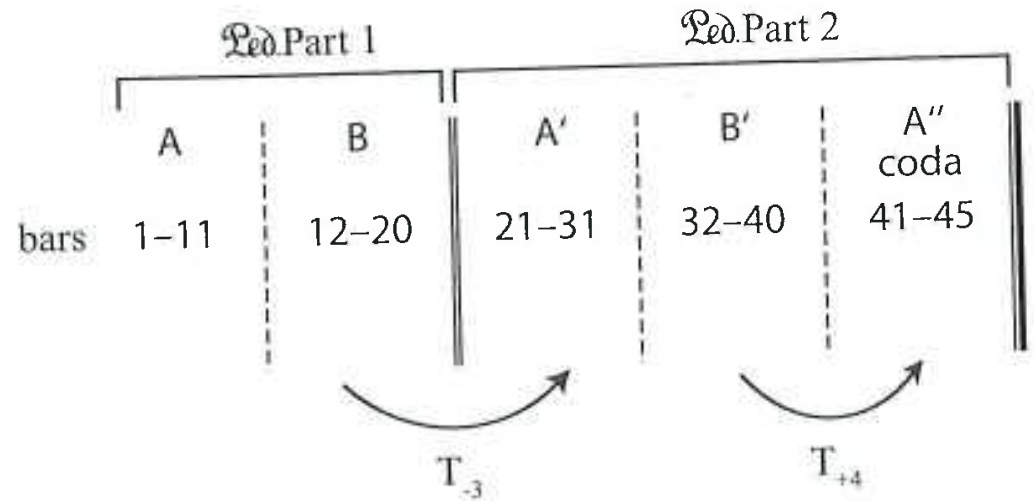

Figure 2 Structure of Poem no. 1

part is virtually identical to the first but has been transposed down a minor third. Thus, Agnew reveals his knowledge of Scriabin's late procedures, using transposition as generator of structure. The coda from b. 41 repeats the opening phrase, but again at a different transpositional level.

It is already evident that this work is generated from a limited set of materials which is rearticulated in different ways. The motive opcrates as a major organising element. A detailed examination of the opening bars reveals what Joseph Straus calls the 'motivic and contextual nature of post-tonal music. ${ }^{30}$

The first eleven bars form the opening statement, which consists of four phrases each starting from the last pitch of the previous one. The symmetry is immediately striking. Whereas the first melodic phrase is symmetrical by way of retrograde, the second is symmetrical by inversion around the arrival point of $\mathrm{G}$. The (014) pitch class set, 'one of the most characteristic trichords in early noncentric music ...' initially dominates. ${ }^{31}$ The (014) pitch class set then gives over to (015), which has also been present since the outset.

The play between $\mathrm{E}$, and $\mathrm{E}$ is significant, as is the resulting interaction between the Eb augmented chord, $\mathrm{E}$ minor chord and in the second phrase the $\mathrm{E}$, major chord that emerges from the melodic line in the first four bars. In fact, the piece as a whole is saturated with pitch class sets $(014),(015),(037),(036)$ and (048). How does one account for collections of different things that seem to be of significance but cannot be related to each other?

By thinking more broadly, we can see that in fact Agnew is working within a larger collection that includes all these smaller motives. This larger collection creates a domain that allows him to freely pass between the smaller elements without relying on functional harmonic progression. If these diverse sets are considered as subsets of the larger collection- $\mathrm{E}_{b}, \mathrm{E}, \mathrm{G}, \mathrm{B}, \mathrm{B}$ - $-(01478)$ or $5-22-$ the music begins to make more sense. It is the only pentad to contain all possible triads - major/minor (036), diminished and augmented (048), the trichords (014) and (015) - as well as the tetrachords (0147) and 'that favorite of Second Viennese composers', (0148) ${ }^{32} 5-22$ is then rich in its possibilities to make tonal allusions

30 Joseph Nathan Straus, 'A Primer for Atonal Set Theory', College Music Symposium 31 (1991), 1.

31 Michael L. Friedmann, Ear Training for Twentieth-Century Music (New Haven: Yale University Press, 1990), 60.

32 Robert Morris, 'New Direetions in the Theory and Analysis of Musical Contour', Muric Theory Spectrum 15/2 (1993), 209. 

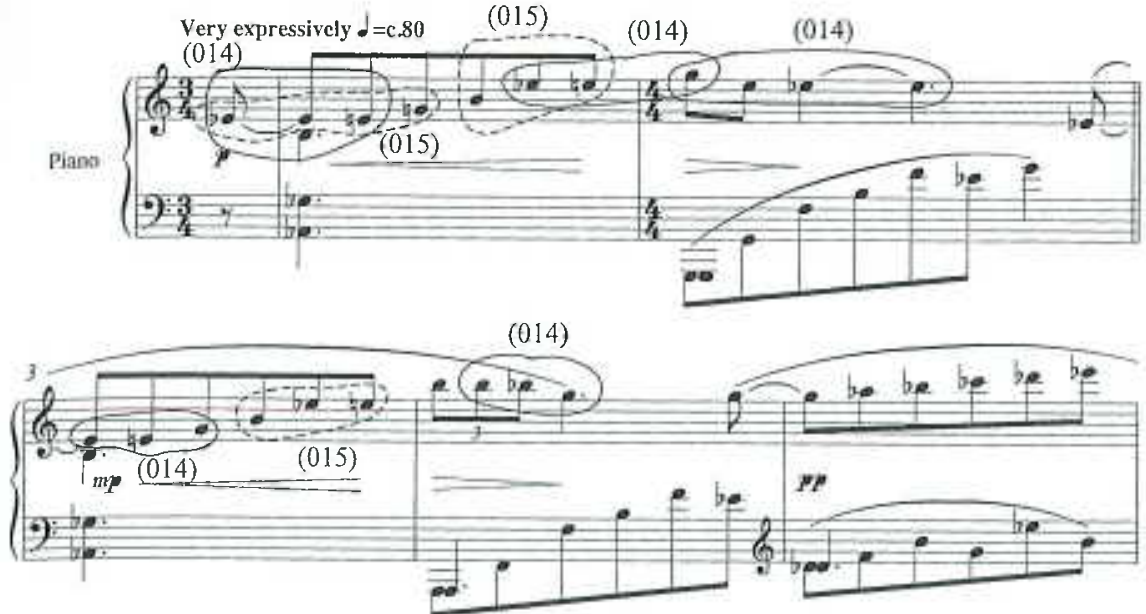

minor third. ig transposiing phrase,

of materials jor organiswhat Joseph

ists of four ymmetry is 1 by way of point of $G$. tly noncenves over to

interaction rase the $\mathrm{E}_{b}$ In fact, the (036) and $\mathrm{m}$ to be of g within a collection - elements s are conor 5-2211 possible ords (014) Viennese allusions

I (1991), 1. : University Iusic Theory
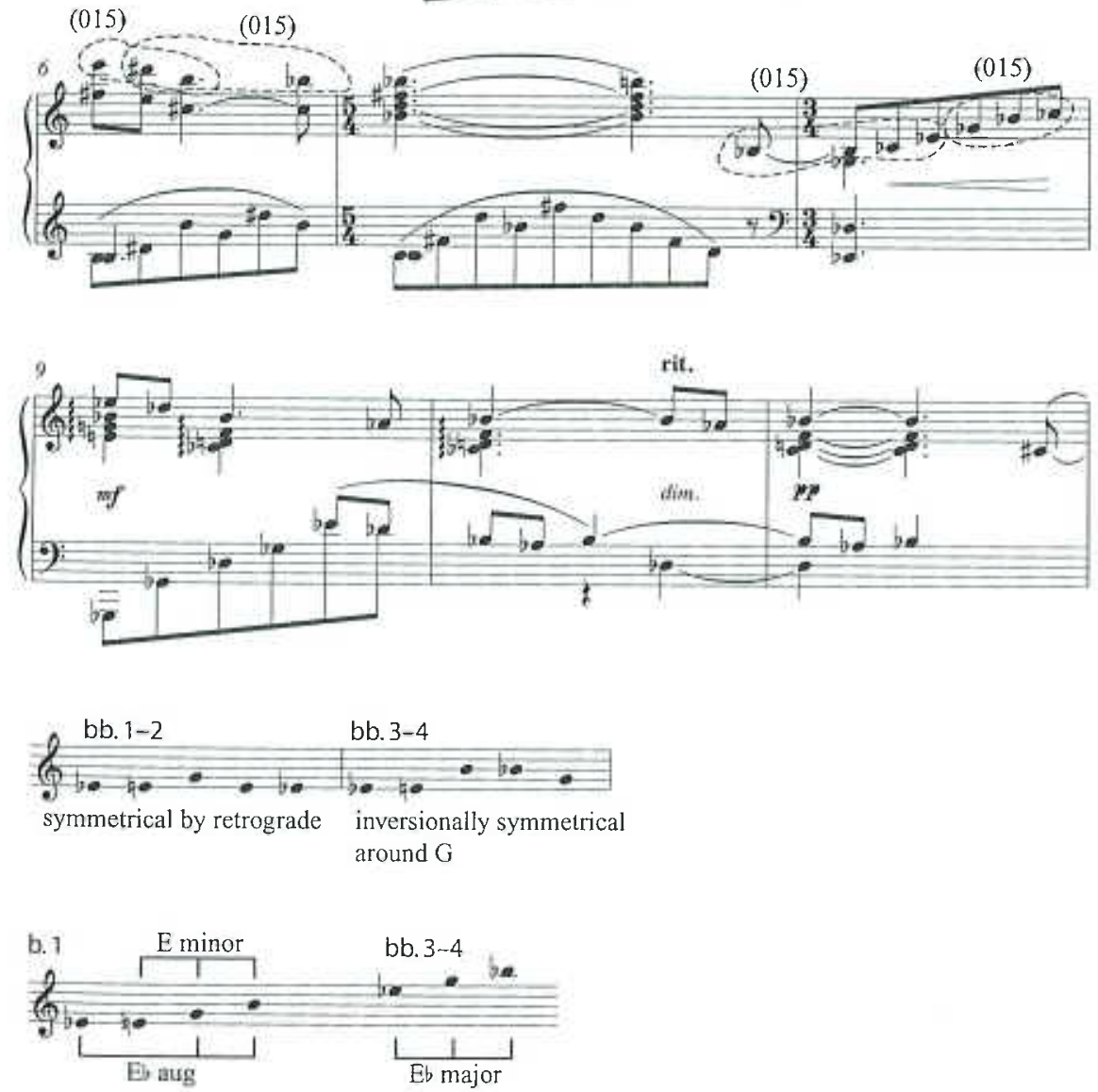

Example 8 Poem no. 1, bb. 1-11.

outside of a tonal framework. It is also, as Agnew shows us in the second phrase, inversionally symmetrical, in this case as two (014) sets around $G$ mirroring the shapes of the beginning and ending of the first two phrases. 


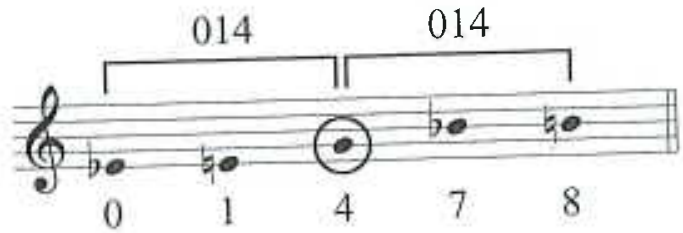

Kate Bor

Example 9 Symmetrical structure of 5-22

It is useful here to think about intervals being 'maximized' in the sense of being expanded out by semitonal slippage seen in the relationship between subsets such as (014) and (015), and (037) and (048). ${ }^{33}$

5-22 permeates the piece in various ways. Comparing the first three phrases, we can see that there is an enriching additive process at work. The opening phrase comprises the subset (0148) as it lacks the $B$ (this appears in the next phrase). In the third phrase, an $A_{b}$ and $D_{b}$ are added. However, the 5-22 can be extracted easily from the melodic line as it constructs the frame of the phrase. The $\mathrm{Bb}$ that appears as the second beat also appears as the final point of pattern completion at b. 7 and the $\mathrm{E}_{b} / \mathrm{D}_{\#}$ acts as the lower neighbour to the high $\mathrm{E} .5-22$ is found in the high points and ultimate destinations of each phrase. If the high points of the phrases found as the downbeats of bb. 2, 4 and 6 are isolated, they form an $E$ minor triad, as is an $\mathrm{E}_{b}$ major triad if the arrival points are seen together (the downbeat of every second beat of the same bars). Combined they create the allimportant 5-22. Furthermore, if the endings of each phrase are viewed alongside each other, it becomes clear that Agnew stays within the collection. The end of each phrase continues to climb the scaffolding of the collection until coming to rest on the $\mathrm{B} b$.

Texturally the work is linear and the initial dovetailing between the two lines supports my parsing of the pitch material. I have been concentrating exclusively on the upper lines of music. If the bass line is examined independently from the treble, we see that bb. 2, 4, 5 and 6 are all derived from the same whole tone collection (even allowing for the fact that Agnew created a bass line by extracting different bass notes).

At b. 7 the whole tone collection changes and we can see then the $A b$ and $G b$ of $b b .1$ and 3 fit into this collection. The addition of $A b$ and $D_{b}$ in the top voice of the final phrase brings the pitch material closer together until it coalesces in the whole tone collection of $b .7$. The whole tone sonority produces a sense of motionlessness, diffusing the tension created by the previous phrases.

Agnew changes the larger referential collection for the section's final phrase bb. $8-11$. This phrase is itself an altered transposition of the opening phrase. The initial (014) motive is here expanded into an (015). Thus the (015) motive common to both collections is kept intact as is the emphasis on $\mathrm{E}_{b}$ and $\mathrm{B}$, both critically important common tones to both collections. The appearance of the $\mathrm{E} b$ and $\mathrm{B}$, as the high point and destination of this phrase harks back to 5-22 and so creates a line of aural continuity. In fact, the change allows these two pitches to remain invariant and maintain their position as the central pitches of the phrase despite the transpositional shift.

33 Ibid., 206. 

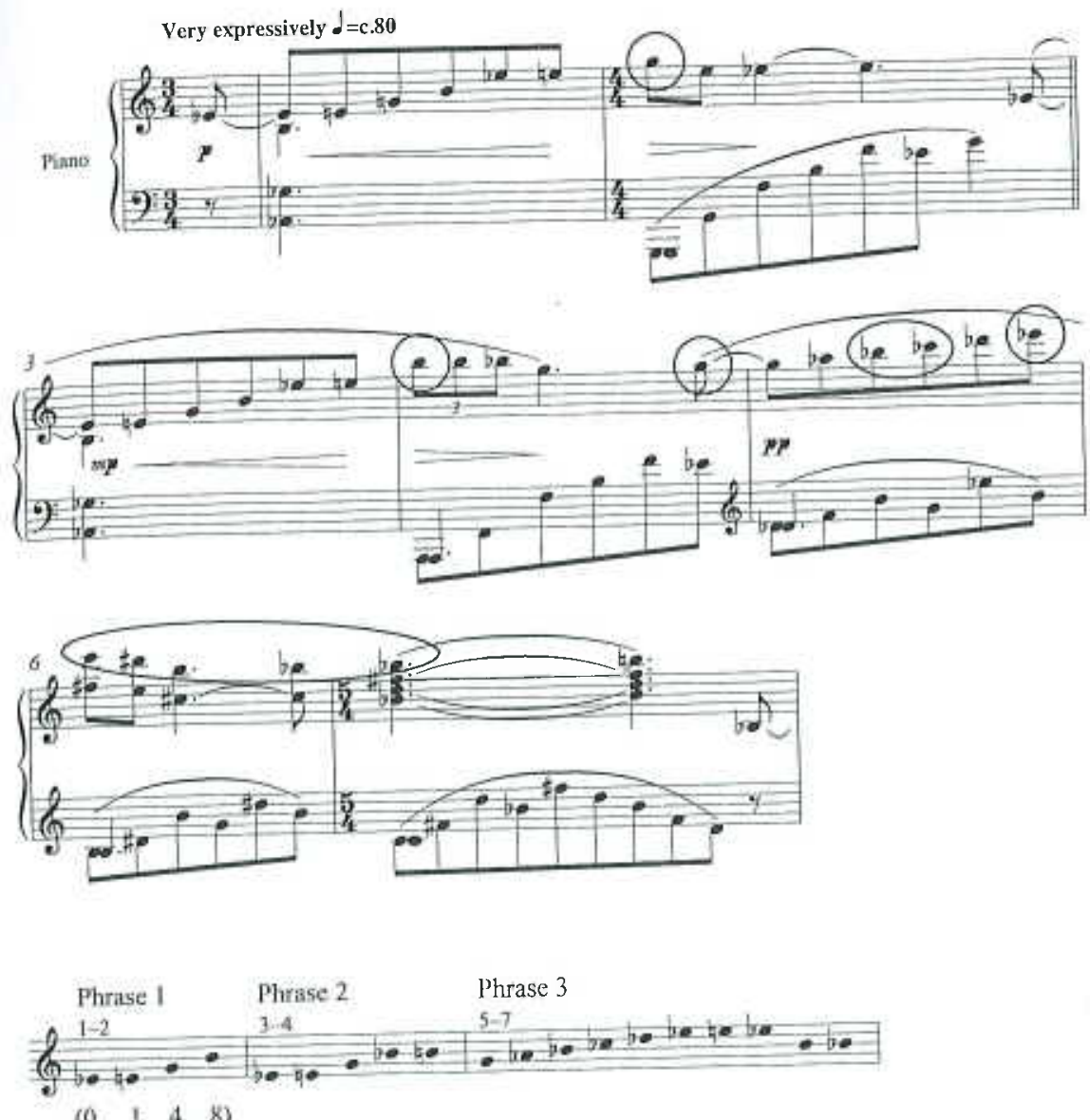

$\left(\begin{array}{llll}0 & 1 & 4 & 8\end{array}\right)$

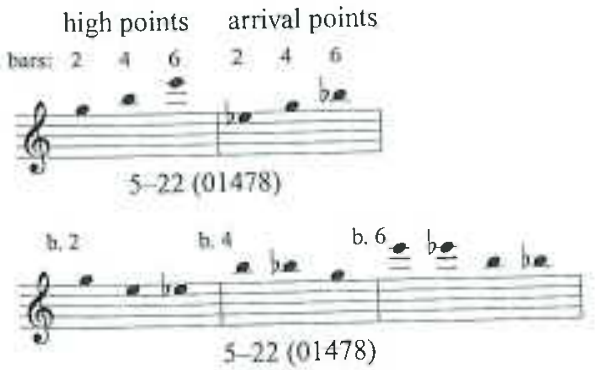

Example 10 Comparison of first three phrases, bb. 1-7

More importantly, the (014) actually articulates the overall structure of the work. If the two major parts comprising the work along with the coda are compared, each features a repeat of the opening phrases at a different transpositional level. The three levels are $\mathrm{E}_{b}, \mathrm{C}$ and $\mathrm{E}$. These notes themselves form the pitch class set (014). It is a case of the micro informing the macro and in projecting 'musical phenomena previously considered to belong solely to the foreground 

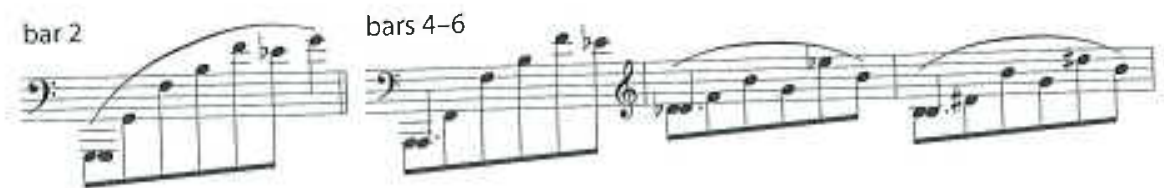

whole-tone collection 2

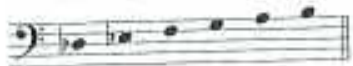

Example 11 LH phrases, bb. 2 and 4-6

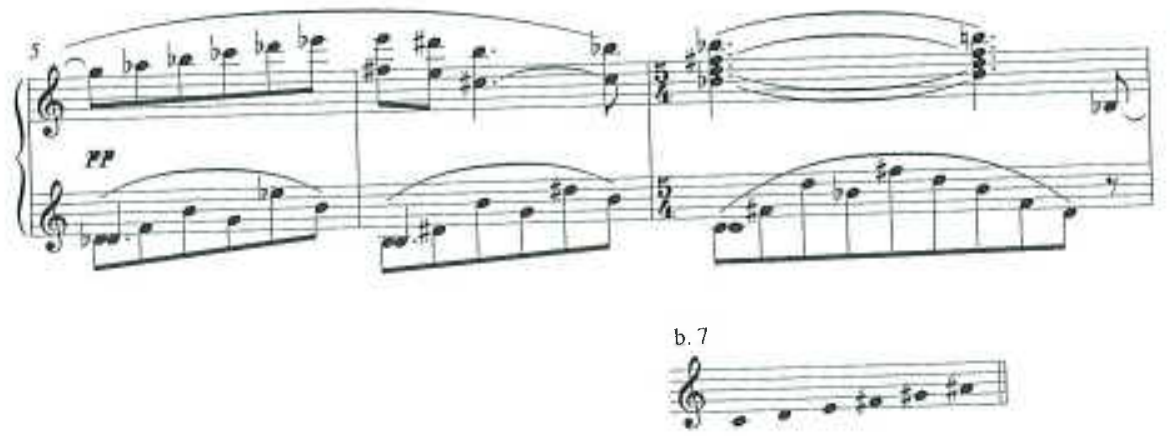

Example 14 Compa

between Scriabin's ninth sonata was announced, Agner the openings are shape of the openi Agnew is in di: investigates Scrial one sonority und 6 for his work. The the octatonic and Example 12 Change to Whole Tone Collection 1 at b.7

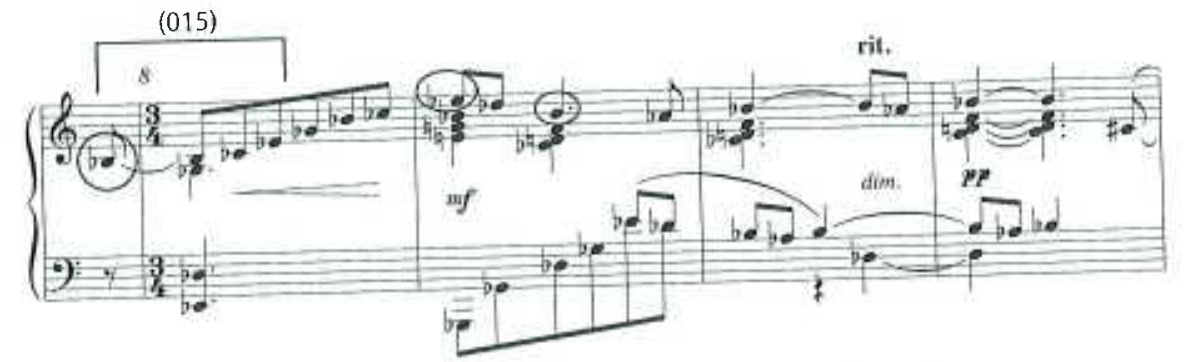
Agnew's sonority

Example 13 Change of larger referential collection for final phrase, bb. 8-11

... onto the structural background' it provides what Robert Morgan has described as 'one of the key characteristics of early modernist music. ${ }^{34}$

Moreover, the final transpositional level has been chosen to allow for a return of the $\mathrm{E} / \mathrm{E}_{b}$ in the melody. The piece ends as it began with a reversal of the important two opening pitches.

Agnew's intimacy with Scriabin's late music is found again in a later sonata that was written at the end of his first five years in London. Here we find a direct link

34 Robert Morgan, 'Secret Languages: The Roots of Musical Modernism', in Modernism: Challenges and Perspectives, ed. Monique Chefdor, Ricardo J. Quinones and Albert Wachtel (Urbana: University of Illinois Press, 1986), 43.

(Agnew, Sonata 1929, o]

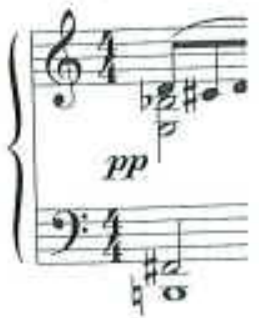

(Scriabin, Sonata no.

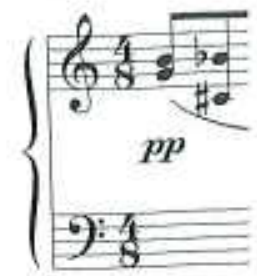

Example 15 Ope 


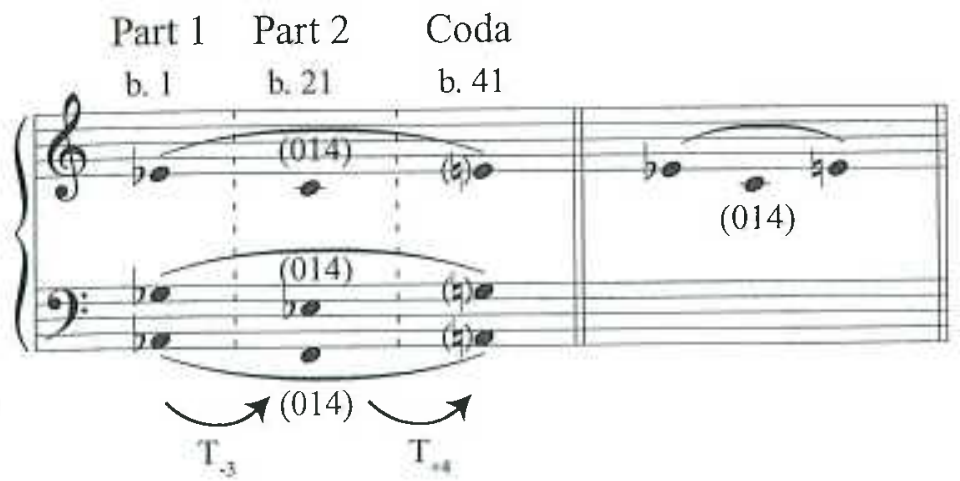

Example 14 Comparison of the major structurat division outlining an (014)

between Scriabin's ninth and Agnew's compositional processes. In fact, Scriabin's ninth sonata was a compositional model in the classical sense. As he publicly announced, Agnew knew and deeply admired the work. The resemblances between the openings are striking: the similarity of vertical sonorities, the thythm, the shape of the opening five-note motive, the voicing and the use of imitation.

Agnew is in dialogue with Scriabin's ninth. Through writing his own work he investigates Scriabin's late compositional techniques. He adopts Scriabin's use of one sonority undergoing various transpositions to create a unique musical world for his work. The opening sonority, like the mystic chord, is a rich combination of the octatonic and whole tone scales although, given the perfect fifth in the bass, Agnew's sonority has a more anchored quality than Scriabin's.

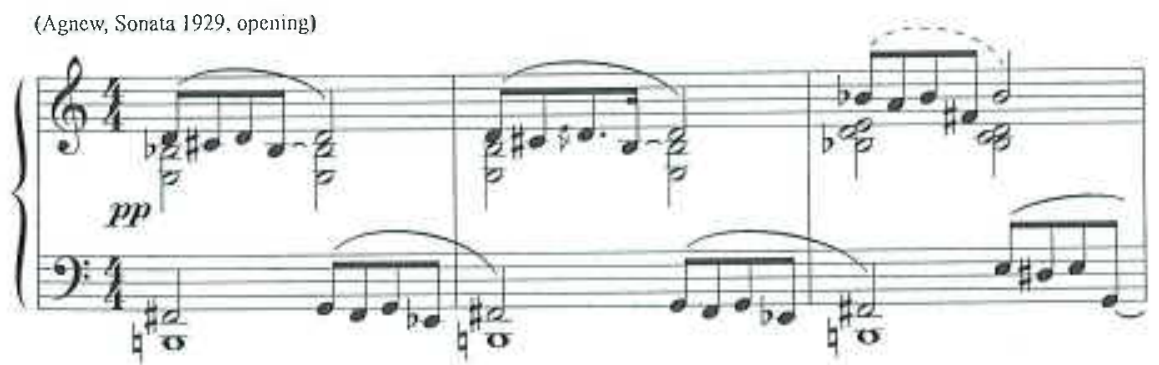

(Scriabin, Sonata no. 9, opening)

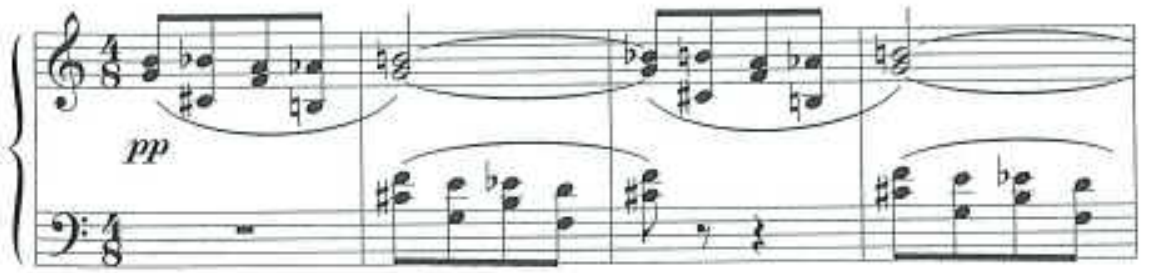

Example 15 Openings of Agnew's Sonata (1929) and Scriabin's Sonata no. 9 


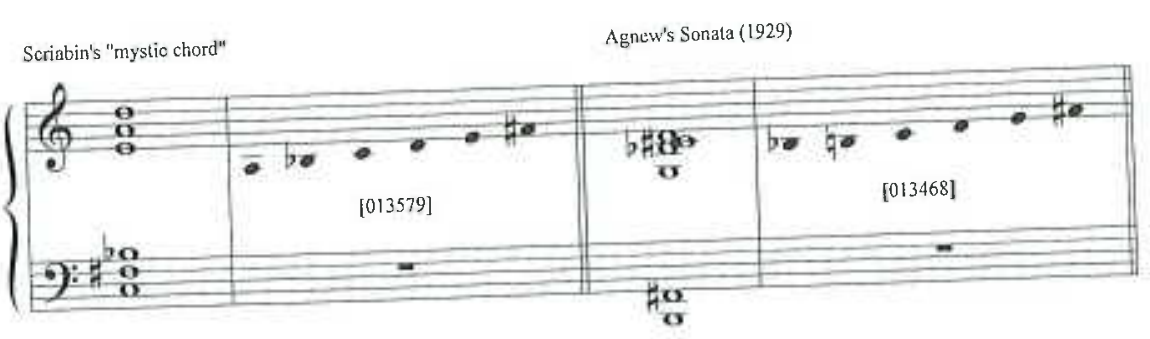

Example 16 Opening sonority from Agnew's Sonota (1929) and Scriabin's 'mystic chord'

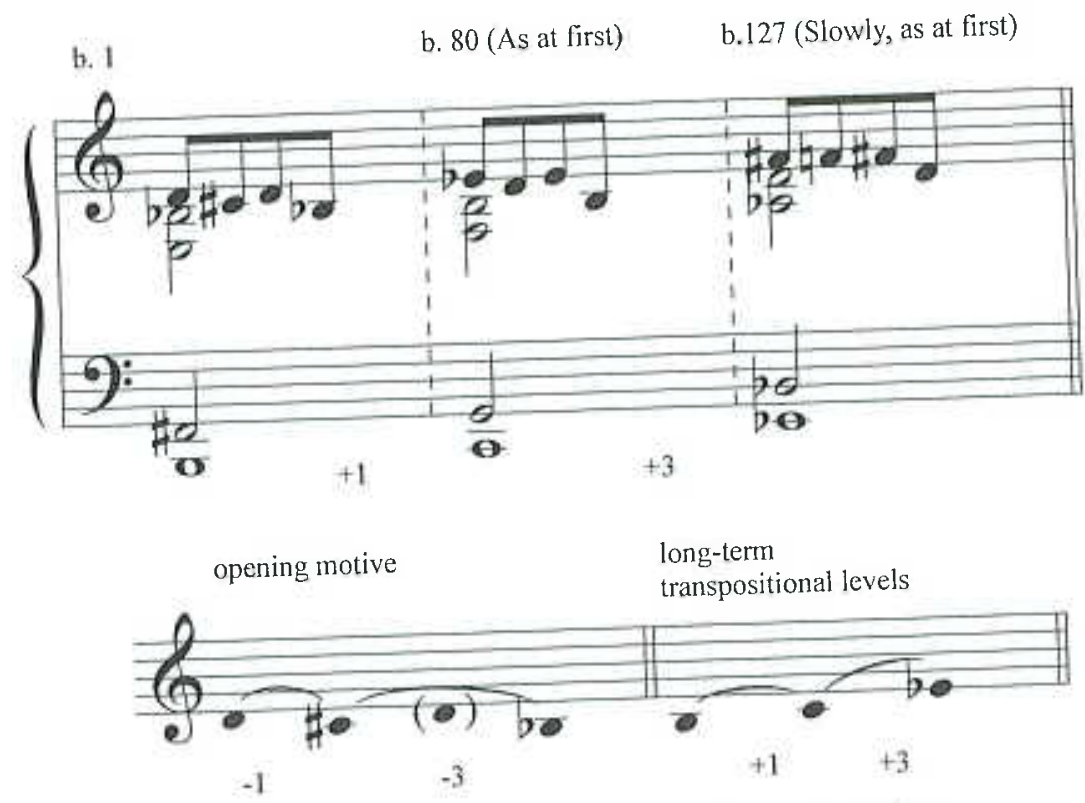

Example 17 Large-scale transpositional levels compared to opening motive

Again, as in the Poem, Agnew uses the opening motive, which is also a pc set (014), as a means of articulating the overall structure through large-scale transpositions and provides the mirror image of the motivic shape in the long term.

Sitsky recalled that many of his compositional colleagues felt this sonata to be the best of the six. ${ }^{35}$ Until now, Agnew's debt to Scriabin's ninth sonata has gone unnoticed. Agnew never published Sonata (1929); the close association to Scriabin's ninth may well have been a reason. ${ }^{36}$ Although written in London, Agnew fell in love with Scriabin's ninth almost a decade earlier in Sydney and the techniques found in the sonata are first tested in the early Poem. How then did Agnew come to be writing this kind of non-tonal music in Sydney before his first journey to London?

35 Sitsky, 'The Piano Sonatas of Roy Agnew', 73.

36. Sitsky has noticed the more obvious debt to Scriabin in this particular sonata but also proposes hat it was the progressive harmonic language of Sonata 1929 that prevented Agnew from seeking its publication. See ibid.

\section{Looking for $\mathrm{Or}$}

An examination of that not only was readily available in contemporary and but here I mean $m$ and also art music French and Russia modern art music I For example, perh: linist Cyril Monk (and possibly Aust after its publicatios performed it along movement of anot] of the musicians w friends and collea Henri Penn and $f$ ists such as Barry Italian music are $f_{f}$ Benjamin and $\mathrm{Mc}$ The following ye together to prem: controversy durin, Pastorale, Malipie cello and piano. times, and hear $\mathrm{e}$ big stir in the mu

More 'difficul' and Schoenberg, much heated disc case of Ornstein upon the imagin particularly ones latest ultramoder of two concert I months after th English appeara: certo and Henr. other reviewed $\dot{C}$ by himself and $s$

37 'Goossens and

38 'Notes', $A M N$ ' attended Orns: diaries, of whi where his arch (Canberra: Nal 


\section{Looking for Ornstein and Scriabin in Sydney}

An examination of the early twentieth-century journals and broadsheets show that not only was much modern European music performed in Sydney, it was readily available in recordings, piano rolls and sheet music. The terms modern, contemporary and modernist are highly contested and intrinsically problematic, but here I mean modern to include all styles of music including jazz, dance hall and also art music. From its onset in 1911 the $A M N$ reviewed performances of French and Russian music, which were seen as exotic presences. In the area of modern art music Ravel, Debussy and English moderns were performed early on. For example, perhaps the foremost champion of modern music in Australia, violinist Cyril Monk, along with pianist Frank Hutchens, performed the Sydney (and possibly Australian) premiere of Debussy's Violin Sonata in 1918 only a year after its publication in Paris. In 1923, Adelaide composer Hooper Brewster-Jones performed it alongside his own violin sonata including also on the programme a movement of another work written in Debussy's final years, En blanc et noir. Many of the musicians who performed modern European music in the early 1920s were friends and colleagues of Agnew, for example Cyril Monk, Winifred Burston, Henri Penn and Alexander Sverjensky, as were many of the most active journalists such as Barry, Cairos Rego and Waters. Reviews of modern Russian and Italian music are found in the press in the early 1920s. For example in 1921 Arthur Benjamin and Monk on tour in Melbourne presented a violin sonata by Milhaud. The following year Penn, Monk, Benjamin and the cellist Gladstone Bell got together to premier works 'by some of the men whose music caused storms of controversy during the last London season'. The programme included Stravinsky's Pastorale, Malipiero's Il canto della Lontanazzo as well as Goossens's Rhapsody for cello and piano. The $A M N$ conceded that it was good to keep apace with the times, and hear everything possible from the ultra moderns, who are making the big stir in the musical melting pot'. ${ }^{37}$

More 'difficult' avant-garde music, for example the music of Bartók, Honneger and Schoenberg, was reported but never heard. It was nonetheless the subject of much heated discussion. This unrealized music could still, as we have seen in the case of Ornstein and Agnew's Dance of the Wild Men, exert a considerable power upon the imagination. Reviews of overseas concerts often appeared in the press, particularly ones that caused a furore. These inevitably included music of the latest ultramoderns. Of particular relevance to this discussion was the appearance of two concert reviews side by side in the $A M N$ in 1914. Published only two months after the actual performances themselves, one covered Scriabin's first English appearance at the Queen's Hall where he performed his own piano concerto and Henry Wood conducted his 'latest' symphonic work Prometheus, the other reviewed Ornstein's infamous London concert in which he performed works by himself and Schoenberg. ${ }^{38}$

37 'Goossens and Other Moderns', AMN 11/5 (1921), 267.

38 'Notes', $A M N$ 3/12 (1914), 381. The Austratian expattiate composer, Frederick Septimss Kelly, attended Ornstein's London concert and gives a first hand account of it in his meticulously kept diaries, of which excerpts have recently been published by the National Library of Australia where his archive is held. See Race Against Time: The Diaries of F.S. Kelly ed. Thérèse Radic (Canberra: National Library of Australia, 2004), 325. 
Ornstein sustained an unusually ferocious attack. In the 1914 review he was accused of mistaking the piano for a punching ball. In 'Futurists in Music', an article written two years later, the attack was resumed: Ornstein's music was declared 'freak music' which made 'one's flesh creep', and once more the use of boxing gloves was recommended. The mockingly derisive tone found in the Ornstein reviews (a tone adopted in an effort to contain the music's transgressive power) is similar to that of the review of Agnew's music as 'Ultramodern Extravagance'. Both reviews suggested that the desired musical effect could be better obtained by simply sitting on the keyboard. Although much of this press had a strong anti-modernist bias, it nonetheless brought the music to public attention for musicians like Agnew to wonder about. The 1916 article on Ornstein even went so far as to include examples of the music thereby allowing interested musicians a glimpse of his musical language. ${ }^{39}$ Monk and another close associate of Agnew, the renowned pianist William Murdoch, discussed Ornstein's music at length in interviews for the $A M N$. $^{40}$

Agnew's professed love of Scriabin's late sonata in 1923 Sydney is startling and demands further exploration. What kind of presence could a 'sophisticated' and 'cosmopolitan' Russian composer with a world view drenched in arcane mysticism have in the 'parochial', 'stagnant' and 'insular' Sydney of the 1920s? In fact Scriabin was surprisingly well covered in the Sydney press, particularly between the years 1921 and 1923 and, of particular significance, it was his late experimental music that attracted most attention. This was apparently a British world phenomenon. This interest also manifested itself in London. If coverage in The Times is taken as an indicator English interest in Scriabin peaked in 1921, a phenomenon possibly related to the overwhelming surge of spiritualism and interest in the occult brought about by the mass grief following the Great War. Using The Times it is possible to ascertain that there were at least seventy-three articles on Scriabin in 1921. This number stands out as unusually high when compared to the surrounding years. In 1918 there had been only two pieces, in 1919 there were twenty-one and forty-five in 1920. In 1922 the number of articles again dropped steeply to a mere twenty-four and did not increase much beyond this in the years to follow. Even in the years 1913 and 1914 that saw Scriabin's two visits to London the articles on Scriabin in The Times did not reach twenty; they were sixteen and eighteen respectively. In Australia the $A M N$ covered Scriabin's important 1914 London premiere of Prometheus only weeks after the event. The Australian press of the 1920 s was cognizant of Scriabin's mature style, describing him as 'very futuristic' and 'this most radical of uitra modern composers'. ${ }^{41}$ In the Sydney Mail, Noskowski identified the new harmonic system, rapturously extolled the virtues of the 'wonderful fifth sonata' and the Satanic Poem, and then expounded with some expertise on Scriabin's unfinished final work, the Mysterium, a work intended to transfigure the world. ${ }^{42}$ In an article for the Conserwatorium Magazine, 'A. Sverjensky and New Russian Music', Noskowski hailed the Russian pianist as an ideally suited interpreter of Scriabin's music. Noskowski's admiration of

"Futurists" in Music-"The Cathedral" (Leo Ornstein, op. 37 no. 2)', AMN 5/8 (1916), 226-7.

40 See C.N., 'A Musical Tea Party with William Mo

(1916), 124; 'Cyril Monk', AMN' Sydney Mail, 19 May 1920, 15.

42 Ibid., 16 .
Scriabin was deeply $\mathrm{fe}$ his most advanced ar his earlier works will est composers'. 43 No: by Peter Dart who de breadth of musical s modern music, was . complaining that $\mathrm{Sc}$ he had earlier in 192 views of Scriabin ar writer Alfred J. Swa:

There were a har performed Scriabin 1921 and 1923, Burs frequently. The $D a$ : 'Sydney has in a sen becoming acquainte in which the music played the third Sor the year with Scrial works were from th his decision to em Agnew and played music. Hutchens st dedication of the $S$ $A M N$. $^{48}$ Due to hi Music Society, W which elicited the Scriabin abided an later $\mathrm{ABC}$ radio $\mathrm{s}$ Belgian pianist $\mathrm{Pe}$ he who played $D_{c}$ received two dedic

There are oth Sydney which ar Society and the e two are themselv year of the Cons allegations of pe Society. ${ }^{49}$ The $\mathrm{S}$, reaching its heyc

43 Noskowki, 'A. S 44 Peter Dart, 'Per!

45 George de Cairs

46 See Cairos Regr

47 'Realm of Musi'

48 Frank Hutchen:

49 For an account (Sydney: New 
iew he was Music', an music was the use of und in the ansgressive Itramodern ct could be $\mathrm{f}$ this press ublic attenn Ornstein $r$ interested se associate n's music at

artling and icated' and : mysticism Js? In fact ly between xperimenworld pheL The Times phenomeerest in the The Times on Scriabin to the surthere were in dropped $n$ the years to London. ixteen and rtant 1914 alian press $\mathrm{m}$ as "very 'dney Mail, the virtues nded with $n$, a work Magazine, I pianist as iration of

)', $A M N 5 / 8$

:, $A M N 6 / 1$
Scriabin was deeply felt: "The day of Scriabine is dawning in Australia and even if his most advanced and modern compositions will never be understood by many, his earlier works will ensure him an immortal position amongst the world's greatest composers. ${ }^{43}$ Noskowki's musical erudition is impressive, a fact also noticed by Peter Dart who describes Noskowski's musical writings as 'exceptional in their breadth of musical culture'. ${ }^{44}$ Cairos Rego, surprisingly, given his embrace of modern music, was one of these who found Scriabin's late music unacceptable, complaining that Scriabin needed a 'keyboard of quarter tones'. ${ }^{45}$ Nevertheless, he had earlier in 1921 informed his readers of the English composer Cyril Scott's views of Scriabin and, in a later issue of the Daily Telegraph, revicwed English writer Alfred J. Swan's monograph on the Russian. ${ }^{46}$

There were a handful of Sydney pianists who threw caution to the wind and performed Scriabin regardless of whether the music was understood. Between 1921 and 1923, Burston, Hutchens, Penn and Wilfred Arlom performed Scriabin frequently. The Daily Telegraph summed up performances of Scriabin for 1923: "Sydncy has in a sense been more fortunate than were other cities in its manner of becoming acquainted with the work of Scriabine', because of the chronological way in which the music was presented to the public. It announced that in 1923 Burston played the third Sonata, Hutchens the fourth, Arlom the fifth, and Penn finished the year with Scriabin's final work, the remarkable Vers la flamme. ${ }^{47}$ The last two works were from the late period. All these performers, including Sverjensky after his decision to emigrate, were personal friends and professional colleagues of Agnew and played his music. Sverjensky and Burston were to record and teach his music. Hutchens studied composition with Agnew for a short time, received the dedication of the Sonata Ballade (1937) and later wrote Agnew's obituary for the $A M N .^{48}$ Due to his position on the repertoire selection committee of the British Music Society, Wilfred Arlom was partially responsible for the programming which elicited the response in 'Ultramodern Extravagance'. Arlom's love of late Scriabin abided and he became a major exponent, appearing frequently on Agnew's later $A B C$ radio show playing, among other things, Scriabin's late sonatas. The Belgian pianist Penn was early on identified as part of the 'ultra modern set'. It was he who played Dance of the Wild Men at Agnew's farewell concert in 1923 and received two dedications: the Toccata tragica (1922) and $A$ Dance Impression (1927).

There are other possible explanations of an earlier presence of Scriabin in Sydney which are connected to the enlivened activities of the Theosophical Society and the establishment of the New South Wales Conservatorium. These two are themselves, as we will see, inextricably bound together from 1915, the year of the Conservatorium's foundation. In 1914, C.W. Leadbeater, escaping allegations of pederasty, decided to move to Sydney to lead its Theosophical Society. 49 The Society bloomed with the presence of such an exalted member, reaching its heyday in the twenties. Early the next year Belgian-born British

43 Noskowki, 'A. Sverjensky and New Russian Music', Conservatorium Magazine 4/6 (1923), 11.

44 Peter Dart, 'Periodicals', in Currency Companion to Music and Dance in Australia, 509.

45 George de Cairos Rego, 'Music', Daily Telegraph, 2 July 1921, 8.

46 Sec Cairos Rego, 'Music', Daily Telograpb, 5 February 1921, 8.

47 'Realm of Music: Seriabine's Music in Sydney', Daily Telggraph, 8 September 1923, 13.

48 Frank Hutchens, 'Roy Agnew: An Appreciation', AMN 35/6, 6-7.

49 For an account of these events see Jill Roe, Beyond Belief: Theosopby in Australia, 1879-1939 (Sydncy: New South Wales University Press, 1986). 
Kate Bon

musician and committed thcosophist Henri Verbrugghen accepted the position of Director at the New South Wales State Conservatorium scheduled to open the following year. The convergence of these events was not coincidental.

From the outset there was a close tie between the two institutions. The Conservatorium during the Verbrugghen years hosted several lectures by such eminent Theosophists as C. Jinarajadasa (who was recruited as a boy in Ceylon by Leadbeater and later became president of the Theosophical Society) and Leadbeater himself. ${ }^{50}$ Verbrugghen, despite his personal dislike of modern music, was a good Theosophist and gave a lecture with the rarefied title 'Light and Music' in 1922 in which he discusses Scriabin's synaesthetic theories on colour and music, going so far as to mention the tastiera per luce, a colour organ, developed for the symphonic pocm, Prometheus. ${ }^{51}$ Diane Collins, in her history of the Conservatorium, writes that, "in 1916, in overwhelmingly Anglo-Celtic Sydney, the new Conservatorium must have seemed like a hotbed of cosmopolitanism.' The international character of the Conservatorium, she continued, 'must have encouraged the notion that art music was a world apart, an exotic import, a cultural curiosity in Australia., ${ }^{52}$

From the outset Theosophy was an orientalist enterprise borrowing extensively from a range of Eastern religions and philosophies. It was founded on idealistic notions of progress, free thought and cultural advance. In their Australian journals, theosophists wrote of the unjust treatment of Aboriginal people, advocated the humane management of prisoners and animal rights, pioneered new educational approaches such as the Kindergarten, embraced Eurythmics and wrote on the merits of vegetarianism. ${ }^{53}$ They were not unlike the Socialist 'cranks' against whom Orwell vented his vitriolic spleen in Road to Wigan Pier, in a viciously funny, if unfair, description:

In addition to this there is the horrible-the really disquieting-prevalence of cranks wherever Socialists are gathered together. One sometimes gets the impression that the mere words 'Socialism' and 'Communism' draw towards them with magnetic force every fruit-juice drinker, nudist, sandal-wearer, sexmaniac, Quaker, 'Nature Cure' quack, pacifist, and feminist in England. ${ }^{54}$

Theosophists were accepting, even encouraging, of experimentation in the arts. Jill Roe has argued that, 'theosophy appears to have played a vital role in the emergence of modernism' 55 Soon after, she refers to Bernard Smith who, when "pondering the origins of modernism in Australia, proposed that "a thorough account of the history of spiritualism, theosophy, and anthroposophy in Australia as abroad is much more relevant than say Einstein's theories"'. 56

50 For example a report on a lecture by Jinarajadasa appears in the Conservatorium Magazine 15 , (1919) 4-6. See also C. Jinarajadasa, "Music as the Synthesis of Emotional and Intellectual Activity', Musical Ausinalia $1 / 6$ (1920), 7.

51 Henti Verbrugghen, 'Light and Music', Musical Autratia 3/4 (1922), 25.

52 Diane Collins, Sound from the Stabies (Mclbourne: Allen \& Unwin, 2001), 92

53 Examples of these can be found in Auscralian theosophical journals such as Advance! Arstralia, The Star in the East and Theosophy in Awstralia.

54 George Orwell, The Road to Wigan Pier (San Diego: Harcourt Brace, 1958), 174.

55 Roe, Beyond Belief, 318.

56 Bernard Smith, 'Wrestling with Modernism: MeQueen's. "Black Swan of Trespass", Meanjin 38/34 (1979), 523. Cited in Roc, Beyond Belief.
It was high cultur jazz were regarded a: supreme position an century Romantics. pure than painting 0 was not merely to et transcendence. Duri semination of high $c$ izing concerts, start their halls as concer1 after the initials of uplift the listeners. ${ }^{5}$ general civilizing an 'prized theosophica. mystic, Cyril Scott. that 'Australian the the sources of innov

One Sydney the music, in particula Campbell was proli ist, violist and pian academic Ellison modern music. She sophical journals. A she presented a free title: 'Modern Mus jazz to modern mu message to the pre The lecture touche as the influence of the address, but wa cles to him alone. spirit who advocat Scriabin concert tc a Russian pianist, music. The highlig sonata. Campbell : known strands of upon during the brought to public :

57 Roe provides an o

58 Ibid., 315.

59 Ibid.

60 Concert program Sydney.

61 Phyllis Campbell Phyllis Campbell entitled 'A Modes 
position of to open the Itions. The res by such n Ceylon by ociety) and dern music, 'Light and $s$ on colour gan, develstory of the Itic Sydney, politanism.' "must have port, a cul-

extensively on idcalistic ralian jour, advocated new educaid wrote on $1 \mathrm{ks}$ ' against a viciously role in the who, when i thorough n Australia

Magazine 15 , ] Intellectual

ice! Australia,
It was high culture the theosophists sought to advance; popular musics such as jazz were regarded as degenerate and diseased. For them, classical music held the supreme position among the arts for the same reason that it had for nineteenthcentury Romantics. Its ineffability-its inability to represent-rendered it more pure than painting or literature and therefore closer to the spiritual realm. Music was not mercly to entertain people but rather to transform them, to bring about transcendence. During the '20s, theosophists were particularly active in the dissemination of high culture, focusing on the promotion of classical music-organizing concerts, starting a Music-Lovers Club, founding an orchestra, providing their halls as concert venues, even founding their own radio station, 2GB (named after the initials of the heretic Giordano Bruno), which aimed to educate and uplift the listeners. ${ }^{57}$ Roe reports that $2 \mathrm{~GB}$ was to be 'resolutely highbrow'. In this general civilizing and educating endeavour two composers in particular emerge as 'prized theosophical figures', ${ }^{58}$ Scriabin and the English composer and ardent mystic, Cyril Scott. These composers provide important exceptions to Roe's claim that 'Australian theosophy in the late twenties did not take the observer close to the sources of innovation in the arts, that is, European innovation'. 59

One Sydney theosophist, Phyllis Campbell, was tireless in her advocacy for music, in particular modern music and especially that of Scriabin and Scott. Campbell was prolific as a composer, poet and dramatist, and active as a violinist, violist and pianist. She left England in 1920 to marry the Sydney University academic Ellison Campbell. Once in Sydney she busied herself promoting modern music. She lectured and wrote extensively on modern music in theosophical journals. As part of a lecture series for 'Crusade for a Beautiful Australia', she presented a free lecture at Adyar Hall (the Society's major hall) with detailed title: 'Modern Music: What it is and what it is not ... Included: The relation of jazz to modern music. The use of discords. How to listen to modern music. Its message to the present age. Where is it leading us? Is it spiritually uplifting? ${ }^{60}$ The lecture touched upon composers such as Stravinsky and Schoenberg as well as the influence of non-Western scales on modern music. Scriabin appeared in the address, but was later to demand her undivided attention. She dedicated articles to him alone. In 'Lives of Great Men: Scriabin' she hailed him as a pioneer spirit who advocated the experimental in art. ${ }^{61}$ In 1927 she organized an allScriabin concert to be performed by Scriabin's personal friend Paul Vinogradoff, a Russian pianist, who had Scriabin's stamp of approval as an exponent of his music. The highlight of the programme was the developmentally important fifth sonata. Campbell and the Theosophists are one fascinating example of the lesserknown strands of Sydney's musical history, some of which have been touched upon during the course of this discussion, but many of which remain to be brought to public attention.

57 Roe provides an overview of these activities. See Roe, Beyond Belief, $297 \mathrm{ff}$.

58 Ibid., 315.

59 Ibid.

60 Concert programme. Held in the Phyllis Campbell Archive, University of Technology, Sydney.

61 Phyllis Campbell, "Lives of Great Men”: Scriabin', Advance! Australia 2/6 (1927), 261-4. The Phyllis Campbell Archive also contains a draft copy of an article by Campbetl on Cyrit Scott entitled 'A Modern Musician-Cyril Scott', written in Sydney in 1922. 
The presence of Scriabin touches almost all writing on Agnew's music after 1921. Thorold Water, in particular, was deeply uneasy about it, finding it a strange exotic presence needing, if not exorcism, then a kind of sanitizing, even masculinizing, process. Scriabin was seen as foreign, a dandy, effeminate, almost poisonous in an overripe decadent way. ${ }^{62}$ Agnew's interest in this 'decadent modern', who epitomized what many understood as all that was wrong with exhausted and jaded post-war Europe, coincided with an emergence of Norman Lindsay's new artistic neo-Nictzschean Dionysian creed elucidated by himself and his supporters in the short-lived journal Vision. This was a credo that promoted energy, youthfulness and vitality; a healthy robustness particular to the virile and 'alive' Australian artist which contrasted starkly to the neuroses of the decrepit European. ${ }^{63}$ These attitudes are present in the persistent line presented by Waters that, although Scriabin influenced Agnew's music, Agnew's music was more masculine and vital; it resisted 'infection' from the Russian's perceived effeminacy. 'His was', in Waters's own words, 'a more masculine Scriabin element'. ${ }^{4}$ Others, such as the critic for Musical Australia, however, revealed a greater level of disinterest in their appraisal of Agnew in May 1923:

At present his style and outlook are far removed from the modern British school as exemplified in Ireland, Vaughan Williams and Frank Bridge. Agnew more nearly resembles Scriabine in his harmonic colour and emotional intensity. ${ }^{65}$

For Waters, however, it was more reassuring to say that by 1927 Agnew had broken away from the seductive power of Scriabin and had turned instead to the 'healthier' Celtic Twilight for his inspiration. 66 The fact that his fascination for both Scriabin and things Celtic went hand in hand was expediently ignored.

62 In August 1927, an article appeared in the $A M N$ claiming that although Agnew had been under Scriabin's 'spell', he had not developed any of the Russian's 'metaphysical sickness'. See 'Roy "Opuses": Fantasie-Sonata and Others', $A M N$ 17/1 (1927), 13. In 1936, in an ring the fact the readthat there had been a time when 'h work escaped the somewhat nauseating element of the Russian's later work'. See 'Roy Agnew's New Sonata: Publication is Australian Venture', $A M N$ $26 / 10(1936), 23$.

63 For a discussion of the promotion of Australian culture as a bealthy and vitul alternative to its Curopean counterpart Eurtistory, cd. F.B. Smith S. L. Goldberg (Surry Hills, NSW:

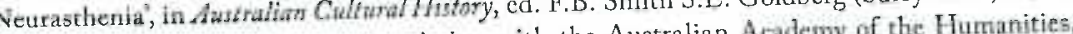
Cambridge University Press in association with the Australian Acad 1988).

64. 'Austalia and Its Composers: The Modernism of Roy Agnew', $A M N$ 21/2 (1931), 14. This rejecrion of Scriabin was not peculiar to Waters, Australia or this time period. As Susan Garcia has argued, 'Few composers have been subjected to such vicious diatribes. Scriabin, by merging an eclectic set of mystical, erotic, satanic and messianic vision with his music, gained many isciples [including Agnew], on the one hand, yet on the other left himself open to sharp condemnation by many musicians, critics, and scholars throughout the present century'. See Susanna Garcia, 'Scriabin's Symbolist Plot Archetype in the Late Piano Sonatas', 19tb-Century Music 23/3 (2000), 273.

65 'Mr. Roy Agnew: Pianist-Composer'.

66 This interpretation of Agnew's stylistic development first appears in 1928 in the $A M N$. See 'Roy Agnew Returns- A Twelve Months' Visit', $A M N 17 / 12$ (1928), 26. It is reiterated throughout the Anew Modernism of Roy Agnew' and 'Roy Agnew's New Sonata: Publication is Australian Venture'.
Agnew's admiratio Sonata was express Scriabin's ninth son merci were written a Sonata and Sonata (. Theosophy and oth in no way perceive bound up with larg 1917 this was felt pa Agnew's debt to Sc The British Austral of Scriabin'. ${ }^{67}$ To fi controversy surrous

Agnew's music ple of belatedness hand', is unhelpful this kind of music such, it stands as $\mathrm{F}$ who make up th imposed by moder ity was the result the case of Austra insight that the $t$ God' is instead 'a culture ... a gestu had also contribut "Tradition and th" when we praise a j anyone else', and : dice we shall ofter work may be thos most vigorously'. makes a similar $\mathrm{p}$ vokes the most or

In the early de For the neoclassic Alexander Scriab Memos in the BI broadcast of his wrote that 'the 1 interest listeners Drewry, was mo

67 'An Australian' 68 Roland Barthes 146.

69 'T. S. Eliot, 'T, Criticism (Lond

70 Charles Rosen, 
usic after a strange masculist poisonmodern', usted and say's new supportd energy, and 'alive' decrepit oy Waters nore masfeminacy. 4 Others, of disin-

snew had ad to the ration for ignored.

been under $\therefore$ Sce 'Roy 1936, in an 2 to the fact ut the readlent of the ture', $A M N$

lative to its es on Malc [jills, NSW: lumanities, ined many sharp conitury'. See th-Century

V. Sce 'Roy ughout the $v$ ' and 'Roy
Agnew's admiration of the American composer Edward Macdowell's Keltic Sonata was expressed in the same interview in which he declared his love of Scriabin's ninth sonata. Deidre's Lament, the Ossianic Sonata and Le belle dame sans merci were written around the same time as his Poem no. 1 and before his Fantasie Sonata and Sonata (1929). Yeats, the father figure of the Celtic Twilight, embraced Theosophy and other streams of occult magic in addition to Celticism; they were in no way perceived as mutually exclusive. The Australian critics' anxiety was bound up with larger questions of national identity and fear of the foreign. After 1917 this was felt particularly in the fear of things Russian as potentially Bolshevik. Agnew's debt to Scriabin was made public knowledge on his arrival in England. The British Australasian introduced him to London as 'a modernist, and a disciple of Scriabin'. ${ }^{67}$ To further titillate the readers, the journalist then raised the recent controversy surrounding his music in Sydney.

Agnew's music reveals its influences readily. But to understand it as an example of belatedness and colonial mimicry, or to hear it as Covell did as 'secondhand', is unhelpful and limiting. To transcend the national boundaries and view this kind of music in an international context removes us from these concerns. As such, it stands as part of a much larger body of music of other 'minor' composers who make up this early twenticth-century transitional world. The pressure imposed by modernism's demand for originality (in many instances this originality was the result of borrowings from non-Western cultures) is compounded in the case of Australian culture. It is helpful in this context to reinvoke Barthes's insight that the text, rather than emanating from what he called the 'AuthorGod' is instead 'a tissue of quotations drawn from the innumerable centres of culture ... a gesture that is always anterior, never original: ${ }^{68}$ Earlier, T.S. Eliot had also contributed to the discourse of artistic originality in his influential essay 'Tradition and the Individual Talent', in which he notes our 'tendency to insist, when we praise a poet, upon those aspects of his work in which he least resembles anyone else', and suggests instead that, 'if we approach a poet without this prejudice we shall often find that not only the best, but the most individual parts of his work may be those in which the dead poets, his ancestors, assert their immortality most vigorously' ${ }^{69}$ Charles Rosen, writing specifically about musical influence makes a similar point: 'The most important form of influence is that which provokes the most original and most personal work. ${ }^{70}$

In the early decades of the last century taste was changing at a whirlwind pace. For the neoclassic composers of the late 1930s, the rich, rhapsodic musical style of Alexander Scriabin, Cyril Scott, Arnold Bax and Roy Agnew was already dated. Memos in the BBC archive after Agnew's death, regarding a BBC Home Service broadcast of his music attest to this. Arthur Bliss, then working for the BBC, wrote that 'the recordings are quite good, but the music is not such as would interest listeners here, except in a very short programme'. His subordinate, Val Drewry, was more dismissive: 'I have heard all these records. The recording was

67 'An Australian Composer', British Australasian, 21 February 1924, 15.

68 Roland Barthes, 'The Death of the Author', in Image-Music-Text (London: Fontana, 1977), 146 .

69 T. S. Eliot, 'Tradition and the Individual Talent', in The Sacred Wood: Essays on Poetry and Criticism (London: Methuen, 1960), 48.

70 Charles Rosen, 'Influence: Plagiarism and Inspiration', 19tb-Century Music 4/2 (1980), 88. 
quite good, but the material is not. It is all very meandering, and a great deal of it is so much alike that it cancels itself out. ${ }^{71}$

Such comments spcak not only to changing musical taste, but also hint at the power relations behind Britain and Australia's complex relationship. Agnew's later career reflects many of the sacrifices, pressures and strains an Australian composer, or more generally an Australian artist, had to make or endure to pursue a professional musical career in the British world. His music underwent a noticeable stylistic shift during his first period in London. It became simpler and modal: in short more 'pastoral'. His example offers a particular instance of the ambivalences and contradictions that existed between Britain and Australia, a topic which however lies outside the scope of this article. An ultramodern and Bolshevik in his early life, Agnew was passé before his death and 'clotted cream' by the late 1960 s. His early period offers a fascinating glimpse into Sydney's musical scene in the 1920 s, revealing a rich and fertile cultural field; one that had not entirely succumbed to the stupor of English pastoralism. It had more to offer than Sitsky assumed when he described it as 'naive, pretty, sentimental, trivial and often amateurish; ; 72 and Agnew took his place alongside and was undoubtedly strongly influenced by like-minded Sydney musicians. The cosmopolitanism and embrace of the modern that Bruce Johnson and Jill Matthews have uncovered in popular culture of the same period ${ }^{73}$ was also present in the more rarefied corners of the highbrow world of art music.

\begin{abstract}
Sydney of the late 1910s and '20s was not as parochial as music historians have long assumed. The early piano music of Roy Agnew benefited from and reflected the richness and diversity of his surroundings. Through an analysis of representative works from this period and an examination of their cultural context I argue that Agnew's music belongs to the large body of modern music from the early twentieth century described by Jim Samson as 'transitional' and that Sydney's musical elite was aware of and could access the most recent modern European music.
\end{abstract}

\section{About the Author}

Kate Bowan has studied and taught in Australia and the USA. She completed her PhD in music history at the Humanitics Research Centre, ANU. She is interested in early twentieth-century Western art music and its place in broader social and cultural contexts.

kate.bowan@anu.edu.au

71 Val Drewry to Mr A. Beese, 12 January 1944, BBC Written Archives Centre; RCONT 10, Roy Agnew, 1939-1949.

72 Sitsky, 'Piano Sonatas of Roy Agnew', 66.

73 See Jill Matthews, Dance Hall and Picture Palace: Sydney's Romance with Modernity (Sydney: Currency Press, 2005).
Before Co: Perspectiv

DAVID SYMON

\section{Introduction}

The literature $c c$ composer's lifeti of the ballet sui and the Sydney brought Antill is the composer w: some analysis, ' mostly of no $\mathrm{m}$ with the strong was then know: most commenta the theatre) fro masque' based c in 1953, was (as was just sixteen early stage in $A$ to the time of $C$ neverthcless do given the gener years and notx early scores in 1

The first anc $A$ Life of John $A$. may be found includes mentic undocumented. well as perusal examination of comprehensive Manuscript Co plete picture of

1 Sydney: Akr

2. MS 437, Aus be cited as 'A examples fou ms scores he 